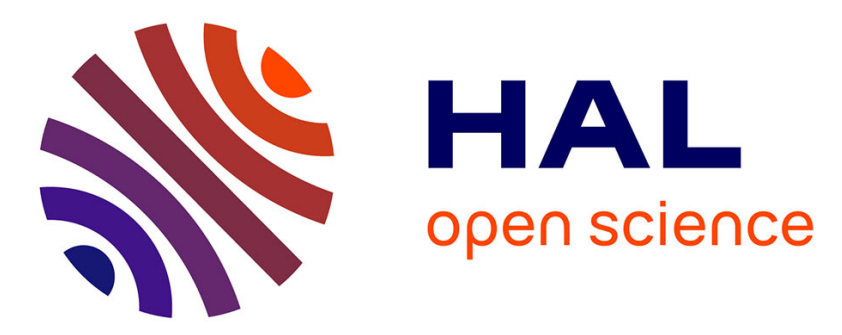

\title{
In vitro $3 \mathrm{D}$ bone tissue models, from cells to controlled and dynamic environment
}

Guénaëlle Bouët, David Marchat, Magali Cruel, Luc Malaval, Laurence Vico

\section{To cite this version:}

Guénaëlle Bouët, David Marchat, Magali Cruel, Luc Malaval, Laurence Vico. In vitro 3D bone tissue models, from cells to controlled and dynamic environment. Tissue Engineering: Parts A, B, and C, 2015, 21 (1), pp.133-156. 10.1089/ten.teb.2013.0682 . hal-01282701

\section{HAL Id: hal-01282701 \\ https://hal.science/hal-01282701}

Submitted on 4 Mar 2016

HAL is a multi-disciplinary open access archive for the deposit and dissemination of scientific research documents, whether they are published or not. The documents may come from teaching and research institutions in France or abroad, or from public or private research centers.
L'archive ouverte pluridisciplinaire HAL, est destinée au dépôt et à la diffusion de documents scientifiques de niveau recherche, publiés ou non, émanant des établissements d'enseignement et de recherche français ou étrangers, des laboratoires publics ou privés. 


\section{In vitro 3D bone tissue models, from cells to controlled and dynamic}

\section{environment}

Guenaelle Bouet ${ }^{1}$, David Marchat ${ }^{2 *}$, Magali Cruel ${ }^{3}$, Luc Malaval ${ }^{1}$, Laurence Vico ${ }^{1}$

${ }^{1}$ Laboratoire de Biologie du Tissu Osseux and Institut National de la Santé et de la Recherche Médicale - U1059, Université de Lyon - Université Jean Monnet, Saint-Etienne, France

${ }^{2}$ Center for Biomedical and Healthcare Engineering, Ecole Nationale Supérieure des Mines, CIS-EMSE, CNRS:UMR 5307, F-42023 158 cours Fauriel Saint-Etienne cedex 2, France

${ }^{3}$ University of Lyon, LTDS, UMR CNRS 5513, Ecole Centrale de Lyon, 36 avenue Guy de Collongue, 69134 Ecully Cedex, France

Full mailing address and contact information for EACH author:

* Corresponding author: David Marchat, Tel.: +33 4774997 01; fax: +33 4774996 94. Email: marchat@emse.fr

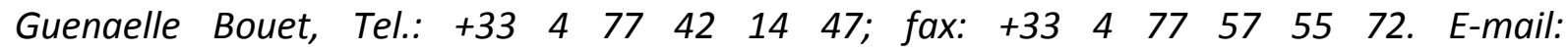
quenaelle.bouet@gmail.com

Magali Cruel, Tel.: +33 4721862 15; fax: +334 774996 94.E-mail: magali.cruel@ec-lyon.fr Luc Malaval, Tel.: +33 4774214 44; fax: +334775755 72. E-mail: luc.malaval@univ-stetienne.fr

Laurence Vico, Tel.: +334 7742 18 57; fax: +334775755 72. E-mail: vico@univ-st-etienne.fr 


\section{Abstract:}

Most of our knowledge of bone cell physiology is derived from experiments carried out in vitro on polystyrene substrates. However, these traditional monolayer cell cultures do not reproduce the complex and dynamic 3-dimensional (3D) environment experienced by cells in vivo. Thus, there is a growing interest in the use of 3D culture systems as tools for understanding bone biology. These in vitro engineered systems, less complex than in vivo models, should ultimately recapitulate and control the main biophysical, biochemical and biomechanical cues that define the in vivo bone environment, while allowing their monitoring. This review focuses on state of the art and the current advances in the development of 3D culture systems for bone biology research. It describes more specifically advantages related to the use of such systems, and details main characteristics and challenges associated with its three main components, i.e. scaffold, cells and perfusion bioreactor systems. Finally, future challenges for non-invasive imaging technologies are addressed.

Keywords: Bone tissue engineering, Perfusion bioreactor, Cell culture, Scaffold, Experimental approaches, Mechanical stimuli 


\section{CONTEXT}

\subsection{Tissue Engineering: concepts}

Tissue engineering is the application of the principles of biology and engineering to the development of artificial living tissues (1). It utilises specific combinations of cells, matrices (referred also as "scaffolds or constructs"), as well as cellular, chemical and mechanical signals. Generally speaking, current applications of tissue engineering can be divided into two categories.

The first category consists of elaborating biological substitutes to restore, maintain or improve tissue functions (1). This therapeutic approach aims to replace/repair damaged human tissues with manufactured tissue-engineered products. This field is quickly expanding due to coordinated and converging technological developments in the creation and/or manipulation of biomolecules, biological materials, cells and tissues, with the goal of ultimately generating pseudo-tissues and organs for transplant. Such therapy will be drastically different from classical prosthesis implants, avoiding integration, interface and wearing-out problems, thus allowing for a longer lived tissue/organ substitution.

The second category of applications of tissue engineering aims to understand the fundamental aspects of cells working in vivo in 3D controlled systems. In fact, in vivo cells reside in a complex three dimensional (3D) micro-environment, encompassing several cell types producing/exchanging many signals, interacting in a dynamic fashion amongst themselves. These cells also interact with an extracellular matrix whose rigidity varies in time and space with the nature and/or maturity of the cell type/tissue $(2,3)$. Moreover, in tissues like bone, cells experience various mechanical stresses (e.g. compression forces). Therefore, in vitro 3D systems, based on tissue engineering principles, strive to reproduce (at least partly) the in vivo environment of cells in a scaffold material. As it was recently 
demonstrated by many studies $(4,5)$ for review), such systems implies the use of perfusion bioreactors to control and monitor biochemical and mechanical signals throughout cell culture.

Such complex models represent the best approach to understand the bone (cell) biology since they allow study of a multicellular microenvironment whose structure, composition, topology and perfusion conditions are adaptable and more realistic, respective to the in vivo situation, than the current two dimensional (2D) standard cell culture method. For instance, in these systems it will be possible to test the effects of chemical substances or characterise stimuli acting locally on cell metabolism in order to understand cellular and matrix changes involved in aging mechanisms and some diseases (e.g. osteoporosis); they will also provide tools for assessing drugs in development in toxicology or pharmacology studies.

The knowledge gained from such experiments will advance our understanding of pathophysiology as well as the prevention, diagnosis and treatment of diseases.

\subsection{From 2D in vitro cell culture to native bone tissue, the missing link}

Bone tissue development and remodeling in living organisms are orchestrated by cascades of regulatory factors interacting at multiple levels, in both time and space.

Animal models provide the full complexity of biological systems (at least within a given species), but they offer limited control of the local environment and scanty real time information. In contrast, traditional cell culture in 2D allows significant control of the cellular environment and a direct access to cellular processes. However, these culture conditions are drastically simplified and hardly reproduce the typical bone environment in the organ/organism, in which (bone) cells develop in a 3D structure subjected to mechanical stimulation. Moreover, it is well established that signal transduction and many other cellular 
functions differ between 2D and 3D culture conditions (6-8). These differences are expected since on 2D substrates the cells have to adapt to an artificial flat and rigid surface. For instance, Elsdale et al have shown that morphological changes in fibroblasts cultivated onto 2D plastic or in 3D collagen gels are different. More precisely, cells cultivated in 3D gels are more similar to connective tissue cells in vivo than on 2D (9). These results highlight the relevance of 3D systems to reproduce in vivo environment.

Cultivating cells in a scaffold provides 3D architecture and potentially mechanical stimulation, but it is only the first step towards 3D in vitro models reproducing the in vivo environment for long-term studies. Indeed, cells seeded in scaffolds and cultivated under static condition (in multiple well plates) tend to reach high concentration at the scaffold periphery, resulting in poor nutrient and waste exchange in the middle of the scaffold and thus cell necrosis in the center of the scaffold. Perfusion bioreactors were designed to avoid this drawback and establish a closely monitored and tightly controlled environment. The perfusion also permits to mechanically stimulate the cells via shear stress (10) for review). These bioreactors can be improved with the addition of a compression system dissociated from or combined with perfusion (11), which is particularly useful and relevant in bone cell studies (e.g. analysis of mechanotransduction (12)).

Three-dimensional artificial models can thus overcome the limitation of current 2D models by providing robust spatial and temporal control of biophysical, biochemical and mechanical micro-environmental cues (13-15). Additionally, the development of such alternative methods follows the ethical regulation drive to reduce the use of animal models.

In this review, we provide an overview of the main concepts, key points and challenges about in vitro 3D cultures dedicated to experimental/fundamental research in bone biology. 
In particular, it focuses on the four main components of such strategy: the scaffold, the cells, the bioreactor and the none-invasive imaging technologies.

\section{SCAFFOLD}

\subsection{Why use scaffolds?}

As mentioned previously, in vitro bone development requires 3D organization to simulate the structure, mechanical properties (i.e. stiffness and strength), composition as well as regulatory cues of the natural $\operatorname{ECM}(16,17)$. 3D artificial models may provide a robust spatial and temporal monitoring of biophysical, biochemical and mechanical micro-environmental cues; this monitoring is unavailable in vivo (14). As such, they are crucial tools for identifying regulators and pathways of bone cell behavior and fate.

\subsection{Ideal scaffold properties}

While the success of an implanted scaffold in vivo will be based on its capacity to be invaded, degraded then replaced by host tissue, the purpose of a scaffold for in vitro experimental application is to provide a structural support for the culture of cells in a controlled 3D environment in vitro. This environment should meet as many as possible of the requirements of the cells used, and ideally mimic the dynamic native niche environment of, e.g. stem cells $(18,19)$. Even though there are no unique scaffold specifications for such experimental applications, scaffold needs to be at least biocompatible and osteoconductive to support cell attachment, growth and differentiation (20). Moreover, although the final features depend on the specific purpose of the in vitro study, several general characteristics and requirements need to be considered for all designs. Besides stiffness $(14,21)$, scaffolds must have adequate mechanical properties to support, if applicable, flow perfusion and 
mechanical stimuli (e.g. compressive strength). Scaffolds for in vitro use do not necessarily have to be degradable (i.e. soluble and/or resorbable). However, the phase and chemical composition, as well as surface chemistry (cell-surface interface), are key parameters that affect cellular responses $(22,23)$. Similarly, architecture influences the interactions between the cells, the media and the material, ultimately controlling the rate and quality of new tissue formation (e.g. extracellular matrix deposition) (14). Both architecture and composition are very important features for this application (24) and are detailed in following subsections.

\subsection{Architecture: A key role}

For a 3D scaffold-based in vitro culture strategy, the scaffold architecture has to allow controlled and homogeneous cell seeding (25), cell response (26), mass transport (27), substrate degradation (28), and mechanical properties (29) throughout the experiment. The scaffold architecture (e.g. geometry, shape, size; as defined below) influences the cell fate both directly (e.g. nutrient accessibility) and indirectly (e.g. adsorption of proteins, local shear stresses). Macroscopic and microscopic architectural features are distinct (Fig. 1). They are generally defined as pore sizes greater than $100 \mu \mathrm{m}$ and below $20 \mu \mathrm{m}$, respectively (for review (30)). Numerous studies have investigated the influence of macro- and microarchitecture on cell response and fate, and both were proved to be of great importance (14).

Macro-scale architecture can be split into macroscopic design (geometric structure) and internal pore structure/architecture, including the shape, size, distribution and interconnection of the macropores. Similarly, the micro-scale architecture consists in the shape (i.e. morphology), size (width and length), orientation (according to the way of perfusion flow for instance) and distribution (ordered vs random) of the micropores. 
Since the 1990s, studies have emphasized the crucial effects of the micro-scale architecture of the constructs on cell seeding and response $(26,31$, for review (32)). Micro-architecture has been shown to improve scaffold osteoconductivity $(33,34)$ and cause intrinsic osteoinductive activity $(35,36)$. These modification may be explained by (i) selective adsorption of proteins from biological fluids $(37,38)$, (ii) increase in specific surface area, promoting dynamic exchange at the biomaterial-matrix-cell interface (39), or (iii) the responsiveness of cells to substrate discontinuities $(40,41)$. For a comprehensive review focused on calcium phosphate ceramics, see (23).

According to the literature, the macro-scale architecture influences internal mass-transports (e.g. supply of nutrients, removal of deleterious waste compounds) (42), cell invasion/infiltration (e.g. seeding) $(25,43)$, tissue ingrowth (e.g. bone, blood-vessel) $(44,45)$, scaffold degradation $(46,47)$, inflammatory response $(48)$, shear stress distribution $(49,50)$, and extensive mechanical properties of the scaffold (e.g. stiffness, compressive strength) (51). Likewise, the mechanical properties of the scaffold affect the intrinsic mechanical stimuli developed at the macroscopic $(51)$ and microscopic cell level $(49,52)$ which, in turn, modify cellular response $(20,27,53)$.

Macropore size has been shown to influence bone cell response in vitro and in vivo $(54,55)$. However, from the literature its effects appear similar for sizes ranging from 100 to $1200 \mu \mathrm{m}$ $(56,57)$. The reason for this lack of logic are most likely the pore size (and shape) uncertainty due to the random internal pore architecture/morphology of the scaffolds used, and the method used to assess macropore and interconnection size (and shape) (58). This indicates that most studies do not exert sufficient control of the macroporous architecture to ensure cell response homogeneity (i.e. cell response related to perfectly defined architectural 
features), As a consequence, the "mean macropore size" (i.e. macropores and interconnections) remains a confounding variable (59), even though it appears as the main macroscopic determinant of the biophysical properties of scaffolds $(25,26)$.

Advancements in engineering and materials has allowed for subtle tuning of scaffold features (e.g. macro-, micro-topography and surface chemistry). These improvements provided the opportunity to more accurately control the biophysical and biochemical microenvironmental cues in 3D biomaterial-based culture systems $(13,60)$. Many engineering methods are used to design and produce 3D scaffolds for tissue engineering applications, including porogen leaching (61), phase separation (61), gas foaming (26), replication of polymer template $(62,63)$, bone machining $(64)$, and others $(65,66)$. Even though the internal scaffold architectures produced from these conventional methods can be modified by changing the fabrication parameters (synthetic materials), or can provide anatomical features with macro- and micro-environmental cues (natural based materials) (24), they suffer from sample-to-sample variations (e.g. random pore distribution and size) and design limitations. Unfortunately, the limits of these conventional methods prevent the structure standardization, as well as the experiment reproducibility; so many detrimental points for the creation of in vitro physiological models. Indeed, biological observations (67), physical (68) and mechanical (69) features, or simulation based on reconstructed images $(70,71)$ are, in that case, valid for one scaffold but not one architecture, diminishing the predictability of results. However, new engineering developments combining computational methods, such as computer-aided design (CAD), and additive manufacturing technologies (AM) (72) are able to overcome these production limitation by providing higher level of control over the design of manufactured scaffolds, with customized external shapes as well as optimized and reproducible internal morphologies (e.g. pore interconnectivity, shape, size and distribution) 
$(25,73,74)$. Recent reviews provide exhaustive classification of the different AM techniques, design methodologies and their limitations for production of scaffold made of different materials $(60,75,76)$. Additionally, Giannitelli et al. reviewed studies relating the influence of some intrinsic architectural features of scaffold (e.g. porous design, pore morphology), controlled by AM fabrication parameters, on their extrinsic properties (e.g. shear stress level and distribution, mass transport, biological behavior) related for instance to the selected cell type grown or the fluid flow perfusion characteristics (75). A conclusion is that a design strategy is needed to match the micro and macro-scale intrinsic architectural features of the scaffold to the conflicting mechanical, mass transfer and biological requirements that it has to fulfil in a given experimental setup. One way to achieve scaffolds with specific target properties is to use computational tools/models to design their structure and AM process for their production (75). This strategy has been used to optimize scaffold design for mass transport $(77)$, mechanical load $(78,79)$, or both $(80,81)$, shear stress at the surface of the pore walls $(49,50)$ and scaffold degradation $(21)$.

Nevertheless, standard empirical approaches are not obsolete, quite the contrary! Recently, Bidan et al. proposed an elegant simple geometric model explaining the shape-dependence of growth in terms of tension and local curvature from static in vitro cell culture experiments and AM HA ceramics (82). In addition to confirm the model in a second article, they cleverly demonstrated that tissue growth into a porous scaffold is a function of pore geometry, specifically the local surface curvature (83); for other trial-and-error assessments on the influence of macroporosity, see $(84,85)$.

Also, beyond the control of the initial scaffold properties, especially permeability and mechanical strength, it is also important to anticipate their evolution during in vitro 
experiments since scaffold degradation processes (e.g. dissolution, resorption, cracks) as well as neo-tissue ingrowth can significantly affect them (28).

Finally, the current limitations of the manufacturing processes result in geometrical discrepancies, generally anisotropic, between the fabricated and the designed scaffold (77, 81). In order to evaluate qualitatively how the fabricated scaffold matches the designed structure, scaffolds should be analyzed by high resolution imaging techniques such as microcomputed tomography ( $\mu \mathrm{CT}$, see section 5). Quantitatively, the high resolution $\mu \mathrm{CT}$ data should be used as input in the simulation in order to determine how these differences of geometry will influence the final scaffold properties (e.g. permeability) (86).

\subsection{Scaffold composition}

Material composition encompasses phase composition (i.e. amorphous or crystalline) and chemical composition (i.e. arrangement, type and ratio of atoms in material). Both associated to the chemical, mechanical and/or thermal treatments experienced by material during the manufacturing process govern the intrinsic chemical (e.g. thermodynamical solubility, hydrolysis susceptibility, chemical surface functional groups), physical (e.g. crystalline structure, wettability, surface charge), mechanical (e.g. stiffness, mechanical strength) and biological (e.g. toxicity, cell attachment) properties of scaffold. These intrinsic properties affect in turn the key early event of protein adsorption and subsequent cell adhesion, growth, differentiation, matrix deposition and function. Indeed, besides microarchitectural features such as roughness (see previous section), the type, conformation and density of adsorbed proteins depend mainly on the surface chemical functional groups, and on the ionic environment and $\mathrm{pH}$ value of the culture medium (for review $(23,86)$ ). The latter can be significantly affected by the degradation mechanisms of the material. In vitro, 
scaffolds can degrade via solution-mediated mechanisms (e.g. dissolution, hydrolysis), cellmediated mechanisms (e.g. resorption, phagocytosis), as well as the loss of mechanical integrity (e.g. surface cracking) $(87,88)$. As degradation products can affect cell fate, they must also exhibit biocompatibility.

From a thermodynamic standpoint most calcium phosphates ceramics are faintly soluble in aqueous media, since their solubility products are low (89). However, John et al. emphasized a clear difference in MG-63 osteoblast-like cells attachment, spreading and growth between the quite insoluble hydroxyapatite (HA) and the more soluble $\beta$ tricalcium phosphate $(\beta$ TCP) ceramics, the former promoting cell adhesion and spreading and not the latter (90). These authors attributed the death of cell on $\beta$ TCP ceramics to the high phosphate and low Ca levels in the material/media interface, resulting from dissolution/reprecipitation mechanism. An equivalent conclusion was reached by Detsch et al. to explain the inhibition of osteoclastic resorption (human monocyte-like cell line U-937) on highly soluble $\beta$ TCP surface (91). Strangely, HA exhibits, as $\beta$ TCP, negligible degree of resorption as well as low rate of bone ingrowth, despite its limited solubility compare to $\beta \operatorname{TCP}(91,92)$. Thus, even if the degradation products of calcium phosphate bioceramics (calcium and phosphate ions) are naturally metabolized (93), their concentrations affect cells fate directly (e.g. cell death) and indirectly (e.g. proteins adsorption). These observations highlight that cell responses are very sensitive to the environment, and indicate that the performance of HA and TCP phases are not optimal. A relevant way to modulate/adjust the intrinsic properties of calcium phosphate (CaP) bioceramics, including solubility, and in turn the biological response consists of a partial replacement of the original constituting ions of the CaP lattice. For instance, the beneficial effects of carbonate ion substitution for phosphate and/or hydroxide 
ions in HA lattice are widely established (92, for review (94)). Thus, managing carbonate content permits control of the rate of resorption and dissolution of synthetic carbonated hydroxyapatite ( $\mathrm{CHA})$ ceramics, which in turn enhance their bioactivity when compared to HA.

Biodegradation of synthetic polymers releases a mixture of oligomers, monomers and other low-molecular products. The rate of degradation is governed by intrinsic properties of the polymer such as molecular weight, chemical structure, copolymer ratio, crystallinity and the proportion of unstable bonds (for review (95)). The degradation products can include harmful or acidic byproducts (e.g. PLA, PGA, puramatrix hydrogel) which are harmful to cell function/survival $(95,96)$. In parallel, other physical and chemical surface properties of biodegradable polymers appear to be detrimental for tissue formation such as hydrophobic surfaces (97) or low cell adhesion capacity (98).

Cell fate is also driven by the mechanical properties of the scaffold and more particularly its stiffness. As in native tissue, cells within a construct respond and adapt to the mechanical and biological stimuli to which they are exposed $(18,99)$. It has been demonstrated by Engler et al., on polyacrylamide gels, that the substrate-level elasticity can specify the lineage specification of Mesenchymal Stem Cells (MSC, see section 3.1) (100). These results were confirmed recently by Zouani et al. (101); see also for review about effect of substrate rigidity on stem cells (102). Thus, scaffold used as hard tissue device, like bone, should exhibit high elastic modulus (103). Consequently, CaP ceramics, which have a stiffness similar to bone (23), have long been used for bone tissue engineering applications. In addition to considerable stiffness, CaP ceramics show biocompatibility, tunable bioactivity and biodegradability (94), and generally more bioactivity than synthetic polymers $(104,105)$. Yet, the brittle nature of these ceramics is a major issue especially for the application of 
mechanical loading in a bioreactor (see section 4). However, this mechanical deficiency could be partly compensated by phase composition adjustment (85) and "topological optimization" (see section 2.3).

The alternatives to inorganic materials for the composition of scaffolds are mainly synthetic organic polymers, as naturally derived polymers suffer high batch-to-batch variability (95). The main advantage of polymers over ceramic, is that scaffolds can be easily produce with tunable micro- and macroscale features. Unfortunately, most porous polymeric scaffolds lack sufficient mechanical strength to withstand mechanical loading (for review (106)).

Combination of inorganic and organic components in a composite biomaterial could overcome their respective limitations, but it would make it extremely difficult to relate the scaffold physico-chemical properties to biological responses within the 3D model. Other materials such as metals (for review (107)) or carbon nanotubes (for review (108)) can display interesting properties for the development of 3D artificial models, provided that their toxicity and interaction with the biological in vitro environment (e.g. cells, proteins) can be controlled.

The development of 3D in vitro models requires to know the influence of scaffold chemistry (e.g. composition, surface chemistry) on cell behavior, and reciprocally to anticipate the influence of culture medium chemistry and cell activity on the scaffold. Thus, an ill-defined scaffold (i.e. not accurately characterized) will never permit understanding and control in reproducible manner the interaction between cells and substrate through adsorbed proteins (98). Therefore, batch-to-batch reproducibility of scaffold chemistry is essential to establish correlation between scaffold features and cell responses. Our experience on in vitro 3D bone model shows that a basic CaP ceramic scaffold with optimized architecture can achieve the 
right permeability, bioactivity and mechanical properties to seed, grow and mechanically stimulate primary cells in a reproducible manner (109).

\subsection{Future Challenges and strategy}

As already stated, robust spatial and temporal control of biophysical, biomechanical and biochemical micro-environmental cues through 3D biomaterial-based culture systems is essential for studying cell regulatory pathways and in vitro tissue regeneration. In this context, experimental models will have to increase progressively their complexity from basic to physiologically relevant structural and functional features (e.g dynamic and complex microenvironment of the native stem cell niche). A core challenge of this strategy will be to uncover the relationship between chemical (e.g. degradation), physical (e.g. microporosity) and mechanical (e.g. stiffness) scaffold properties, and cell signaling (32). This implies the accurate control and characterization of architectural, mechanical and physico-chemical biomaterial features, at micro- and macroscales, from synthesis, through shaping, until the sterilization steps. Unfortunately, physico-chemical properties (for review (104)) as well as architectural features (58) of scaffolds are still too often considered as non-significant parameters and thus become confounding variables; as evidenced by Kumar et al. speaking about the "unexpected sensitivity that cells have for scaffold structure" (67). In most cases, the whole scaffold manufacturing process (e.g. chemicals sourcing, phase synthesis, scaffolding method) is not enough accurate/standardized, and the final product not enough characterized to elucidate the link between scaffold features and biological response (38, $110,111)$. For instance in another study of Kumar et al., is the osteogenic differentiation of hBMSCs, seeded on etched poly( $\varepsilon$-caprolactone) scaffolds, induced by surface roughness or surface chemistry change (112) ? It is also unfortunate that series of studies on in vivo and in 
vitro evaluation of silicon-substituted hydroxyapatite ceramics would have been published without any information about the real phase composition of the samples $(110,113)$, when it was recently shown that even small changes of silicon-substituted hydroxyapatite ceramic phase composition drastically modify cellular responses $(114,115)$.

Defining the appropriate(s) composition(s) and the relevant architecture(s) of these new 3D systems for specific experimental goals remains a significant challenge (32). However, new design concepts and fabrication techniques currently available (e.g. additive manufacturing), even if they still display inherent feature limitations (81), provide alternatives for developing scaffolds with sufficient batch-to-batch similarity in geometrical, mechanical and physicochemical features to enhance our understanding of cell signaling $(82,83)$. To reach this goal both computational simulations and experimental studies are necessary, including extensive characterization of main scaffold features before and during in vitro tests in order to refine the numerical models.

Therefore, we propose that, as an initial step, scaffold design should follow a simple -even simplistic- approach, comprising:

(i) an isotropic macroporous architecture with continuous open pore geometry such as the one based on triply periodic minimal surfaces (TPMS) $(50,74)$. Compared to a random-pore architecture, this "basic" design could simplify both the identification of the variables affecting cellular response (by limiting assay variability and standardizing lab to lab assays), and the numerical simulations of the different physical variables which characterize the 3D biomaterial-based culture system (e.g. fluid flow profile experienced by cells). This architecture could also facilitate a dynamic monitoring of the cells by non-invasive imaging, for instance through confocal microscopy $(50,83)$. 
(ii) a monophasic material with homogeneous and reproducible surface properties. The production of such material implies a perfect control of all production steps from chemical synthesis to sterilization.

(iii) an accurate characterization of the actual chemical, physical, mechanical, architectural and biological properties of the manufactured scaffold by means of experimental techniques (e.g. $\mu \mathrm{CT}$, spectroscopy, mechanical tests, osteoclast culture, degradation experiment), and computational methods (e.g. computer fluid dynamics simulation, finite element analysis). Since the properties of the scaffold are not only affected by cell activity, but also by culture conditions (e.g. mechanical stimulation, fluid flow, media composition), their evolution should be quantified in these conditions, i.e. without cell.

\section{CELL CULTURE}

\subsection{Cell types and sources}

In bone biology, osteoblast-like cells are the most studied because they are easier to obtain, cultivate and use compared to osteoclast-like cells or osteocytes. For a comprehensive review focused on osteoclast-like cells or osteocytes, see (116) (these cells will not be discussed herein). Cells used for in vitro bone studies are either cell lines or primary cells isolated from human or animal tissue. In both cases, these cells display more or less differentiated features, ranging from stem-like cells to osteoblasts. Consequently, the choice of the cell type model (cell line or primary cells? Which cell lines? etc.) will depend on the goal of the study.

A cell line is a homogeneous population of cells with the ability to proliferate in culture without limit, at least in theory, and therefore called "immortal" $(117,118)$. Cell lines are 
obtained from cells isolated from bone tumors (cancer cell line) (119) or from primary bone cells which have undergone a spontaneous genetic change, such as p53 mutation (nontransformed cell lines) (120). Primary cell can also be genetically/artificially modified to be "immortalised", they are then named "transformed cell lines" (121). The advantage of cell lines is the immediate availability of a large numbers of cells without the need for isolation, the ease of maintenance and the homogeneity of the cell cultures. Cell lines are less prone to the phenotypic variability observed in primary cell cultures, but at the cost of some functional characteristics that are lost after immortalisation. Thus, cell lines may not express all tissue-specific characteristics.

For example, the non-transformed murine preosteoblasts MC3T3-E1 cell line (122) is commonly used for its high capacity of differentiation in response to materials (apatite), with or without differentiation medium (123). However, cultures of these cells have been shown to not mineralize as hydroxyapatite but in spots of a mineral of unknown form (124). Human osteosarcoma cell lines, such as MG-63 and SaOS-2, particularly useful in the study of interactions between osteoblasts and materials (125), as well as assessment of biocompatibility and osteoblast differentiation potential $(126,127)$, must also be used with caution. Indeed, the response obtained with these lines may differ from those obtained from healthy cells. As a case in point, Anselme team compared the deformation of the cell nuclei in response to substrate surface topography in "healthy" (HOP), cancerous (from osteosarcoma: OHS4, U2OS) and immortalised (F/STRO-1+A and FHSO6) (bone-forming) cells (128). Cancer cells displayed a strong deformation, immortalised cells showed reduced deformation, while healthy cells were deformed only after short incubation times. Along with other results $(129,130)$, this study highlights the impact of immortalization on the state/responsiveness of the cytoskeletal network, leading to a modified behaviour compare 
to healthy cells $(128)$. Overall (see also $(116,131))$, cell lines are useful for specific studies such as cytocompatibility testing or various stages of osteogenesis investigation, but do not reflect the behaviour of primary cells. Additionally, many cell lines can become unstable with time, and subclones of these cell lines tend to develop in different laboratories, which can lead to different experimental outcomes and results no longer comparable between studies and/or laboratories.

Primary cells provide an alternative to cell lines. They are "unadulterated/healthy" cells, cultivated directly from human or animal tissue. Populations of bone primary cells contain stem cells and osteoprogenitors (i.e. committed but undifferentiated cells). An evident advantage of primary cells is that they can be isolated from genetically modified animals in which the expression of a gene has been cancelled, forced or rendered conditional, as for instance BSP-/- mice used in our laboratory $(132,133)$. This avoids the direct manipulation of gene expression in the culture (e.g. RNA silencing), for which the transfection of the agent, as well as the efficiency and duration of its action are difficult to control.

Many methods are available for the isolation of primary cells from bone. A common one is to digest small pieces of bone explants from long bone, calvaria (from rodent fetus or neonate), mandible or iliac crest with collagenase or other matrix-digesting enzymes $(134,135)$. Primary cells are also regularly isolated from the bone marrow (136).

Bone marrow in adults harbours several types of stem and progenitor cells, hematopoietic (HSC) and non-hematopoietic, the latter including mesenchymal stem cells (MSC). MSC are undifferentiated cells with high proliferation capacity, able to self-renew and differentiate into different cell lineages, generating all mesenchymal tissues, such as bone, cartilage, tendons, muscles and fat (137). In vitro differentiation studies demonstrated the ability to isolate and multiply MSC from cartilage, trabecular bone, periosteum, adipose tissue and 
periodontal ligaments (138-142). However, gene and protein profiles characteristic of these cells are still unclear. Recently, the European Genostem consortium elucidated the biology of stem cells from bone marrow, establishing that the native cells are localised on the abluminal side of endothelial cells of sinuses (143). They showed that stromal cells forming the niche of HSC and bone marrow MSC are the same entities, and that highly proliferating clonal cells, amplified in culture, are "true" stem cells since they display self-renewal and multipotency, similar to HSC (143). However, many questions remain unresolved. It is not clear, for instance, whether the self-renewal capacity of MSC is comparable to that of HSC (143). Thus, several important players in this field consider that the only true test of stemness is in vivo tissue/organ reconstitution from one single MSC, and they contest the notion of a universal MSC as opposed to tissue-specific (e.g. in the bone marrow, skeletal) stem cells (144).

Anyway, the main practical disadvantage of the use of primary cells is that considerable variation may exist between cells of different tissue sources. Cell populations derived from a single tissue source may also be heterogeneous due to variations in the isolation and/or purification technique, or according to passage numbers. For instance, significant changes in contractile force were reported for chondrocyte after only three passages (145). In addition, primary cells are extremely sensitive to the batch of serum used (146-148), emphasizing the importance of the culture medium composition. The addition of certain factors, such as dexamethasone, ascorbic acid and $\beta$-glycerophosphate allows to direct these cells towards the osteoblastic differentiation pathway. Similarly, other inducing media exists to drive differentiation to adipocytes or chondrocytes. Also, in order to improve the homogeneity of marrow-derived populations, it is possible to sort and select cells with antibodies targeting cell type-specific membrane markers (149). 


\subsection{Complex 3D models: cell co-culture}

Tissue engineering mainly uses "minimalist" approaches using a single cell type. In contrast in vivo, the dynamics of the bone tissue - in particular, its remodelling - is based on an intimate cross-talk between different cell types: endothelial cells, matrix-embedded osteocytes, bone lining cells and more particularly osteoblasts and osteoclasts (150).

In vitro osteoclast/osteoblast co-cultures on scaffolds allow the study of the remodeling process and, in particular, the crosstalk between resident osteoblasts and invading, differentiating, and resorbing osteoclasts. Tortelli et al. (151) developed a 3D model of bone by seeding primary murine osteoblasts and osteoclast precursors in a ceramic porous scaffold (placed in multiwell plate). Using this model, the team demonstrated through comparative analysis of transcriptional activities that the 3D environment stimulates osteoblast differentiation which, in turn, induces early differentiation of osteoclasts. Vacanti team also highlighted, in an osteoblast and osteoclast co-culture experiment, the formation of osteoclasts on polymer surfaces previously mineralized by osteoblasts Nakagawa (152).

Osteoblasts and osteoclasts are not the only critical cells for bone remodeling. For a very long time, osteocytes have been ignored because it was assumed that they functioned as place holders in the bone matrix and that all the action took place on the bone surface. However, within the last decade these cells have been shown to act as orchestrators of bone remodeling $(153,154)$. More precisely, several experiments using conditioned medium (i.e. supernatant containing soluble factors from osteocytes) $(155,156)$ or different co-culture methodologies $(155,157,158)$, in $2 \mathrm{D}$ substrate or in $3 \mathrm{D}$ gels $(158,159)$, support the concept that osteocytes regulate the function of both osteoblasts and osteoclasts. Moreover, 
considerable convincing data emphasize the role of osteocytes as mechanosensors, integrating mechanical signals to regulate bone mass (153). Indeed, in experiments mechanically using parallel plate flow chambers, mechanically stimulated osteocytes inhibit osteoclastogenesis (160) and increase osteoblastic activity (laminar flow model, (161)).

In vivo, angiogenesis and osteogenesis are closely linked and stringently regulated. Thus, interactions between osteoblasts and endothelial cells have been extensively studied. Complex cellular crosstalk between these cells have been reported in several in vitro studies $(162,163)$ using different co-culture models. Grellier et al. (164) made an inventory of these models, from the nature of the 2D and 3D substrates (e.g. spheroid or porous scaffolds with different compositions), to the cellular models used (e.g. rat long bone-derived osteoblastlike cells, human umbilical vein endothelial cells or human bone marrow stromal cells) and the crosstalk between these different lineages. Co-culture of either osteoblasts or osteoprogenitor cells with vascular cells led to opposing conclusions about the ability of endothelial cells to induce or inhibit the expression of osteogenic genes (165). Indeed, such interactions depend on the origin and differentiation state of the two cell types, as well as the co-culture system used (2D or 3D substrates). However, when endothelial cells had an inducing effect, the in vitro concomitant mineralization of deposited matrix and formation of blood vessels have not been observed. Thus, there is much more to learn about the chemical and physical signals that drive the coordination of angiogenesis and osteogenesis in vitro.

Recently, Papadimitropoulos et al. (166) developed a more complex in vitro model to mimic bone turnover by co-culturing osteoblasts, osteoclast and endothelial cells. To address the issue of the very short life of osteoclast cells, the authors developed a culture process in two steps. First, cells from the stromal-vascular fraction of adipose tissue, containing both 
osteoprogenitors and endothelial lineage cells, were seeded then cultivated for a week in a perfusion bioreactor. In the second phase, CD14+ human peripheral blood cells were infused into the scaffold via the perfusion system. Non-invasive monitoring techniques (e.g. analysis of typical markers of bone remodeling in the culture medium) were used to quantify the bone matrix deposition and resorption processes, as well as to document the functional regulation of the system via osteoclastogenic and osteotropic factors (166). Unfortunately, these results do not allow to fully characterize the "quality" of the bone-tissue like formed (167). Bone quality encompasses several parameters such as bone remodeling level, matrix composition, bone mineralization degree, matrix and mineral composition. Monitoring of all these parameters are still missing in in vitro studies, which therefore do not established that the "bone-tissue like" material formed in the culture is comparable to "genuine bone".

Nonetheless, all co-culture studies, regardless the cell types used are useful to better understand the crosstalks regulating bone physiology. Most try to come closer to the physiological environment of the cells by using 3D matrices or mechanical stimulation. However, no study combines these two important conditions of the cell environment. It is thus a major issue to co-cultivate cells in 3D models allowing different type of mechanical stimulations.

\subsection{Cell seeding}

The cellular seeding of a porous scaffold is an important step in the setting up of a 3D culture. First, the initial seeding density impacts tissue formation. High cell densities are associated with stimulation of osteogenesis and increased bone mineralisation (168). Classically, a $30 \mathrm{~mm}^{3}$ macroporous biomaterial is inoculated with one million cells $(169,170)$. Second, the seeding protocol also affects the viability and distribution of cells within the scaffold, impacting the subsequent distribution of the tissue formed (171). Uniform cell 
seeding is thus necessary to get uniform cell response within the scaffold and reproducible 3D cell culture.

3D cell seeding is generally performed under static conditions by placing a suspension of cells on top of the scaffold, which will penetrate within the material by capillary and gravity action. Although this standard method is widely used, it may result in low seeding efficiency and non-homogeneous distribution of cells in the scaffold (171-173). The seeding efficiency can be improved by placing the scaffolds in a stirred cell suspension. Spinner flask systems have been used for this purpose. However, the inefficient convection of the interior of the scaffolds can also lead to low cell densities and non-homogeneous distribution of cells (171, 174) with a higher density at the external surfaces (175). To further improve seeding efficiency, a flow of cells in suspension can be forced through the scaffold by means of a perfusion bioreactor. In this case, seeding and cell growth are successively performed without further manipulation, greatly reducing the risk of contamination. The use of perfusion bioreactor for cell seeding, developed in the next part of this review, allows a more homogeneous distribution of cells within the scaffold compared to static seeding or with spinner flask (171-173). However, the effective seeding conditions (e.g. seeding flow) have to be adjusted according to the type of perfusion bioreactor, the scaffold internal architecture, as well as the cell type(s) used.

\section{PERFUSION BIOREACTORS: the solution for in vitro 3D bone model(s)}

Nowadays, it is well established that a perfusion-based bioreactor is the most efficient culture system to homogenise nutrient transport, waste elimination as well as cell distribution, growth and differentiation in the interior of the scaffold $(4,176)$. These systems consist in forcing the culture medium through the cell-seeded scaffold. They are usually 
composed of a scaffold chamber with a reservoir and a pump, all connected by tubing (Fig. 2 A). Many perfusion bioreactors have been designed according to the goal of the study, using various scaffolds, cell types and perfusion modalities (i.e. mode and rate of fluid flow). These systems have been detailed in several interesting reviews $(4,5,177)$. In addition to control and monitor many culture parameters throughout the tissue growth in vitro (e.g. $\mathrm{pH}$, temperature, pressure, nutrient supply, waste elimination), perfusion bioreactors allow to study the role of mechanical cues on cell fate. Indeed, the perfusion and/or loading systems combined with the bioreactor can be used to mechanically stimulate the cells.

\subsection{The media: controlling and monitoring}

In order to live, a cell needs nutrients such as glucose, oxygen, amino acids, fatty acids, vitamins as well as specific factors. Among them, oxygen is much more than a required nutrient, it can act as signalling molecule to affect cell behaviour in several ways (178). Thus, high oxygen concentrations appear toxic to many cells, while low levels of oxygen can promote cell viability (179) and the differentiation of stem cells in vitro and in vivo (180-183). Moreover, while it is clear that the local oxygen pressure is a potent regulator of metabolism and viability of bone cells, the distribution profile of oxygen in bone is currently unknown. Nonetheless, mathematical models suggest that significant oxygen gradients exist between the cortical and cancellous bone, and that the partial pressure of oxygen $\left(\mathrm{PaO}_{2}\right)$ can regulate the physical dimensions of trabeculae and osteons (184). Moreover, it is known that in vivo, the $\mathrm{PaO}_{2}$ is $5 \%$ in peripheral tissues, $6-7 \%$ in bone marrow and $1 \%$ in the endosteal niche (183). It should be noted that these values are low compared to the $21 \% \mathrm{PaO}_{2}$ usually used in classical (2D) cell culture conditions. Apart from oxygen, a recent study showed that glucose concentration is an important factor in maintaining the viability and growth of MSC 
in vitro (185). Deschepper et al. showed that MSC could sustain near-anoxia conditions only in the presence of glucose in vitro and in vivo (186).

Thus, culture conditions and especially the chemical composition and homogeneity of the medium influence cell viability and behaviour. In static conditions, pure diffusive transport ensures oxygen and nutrients supply to the interior of the scaffold only to a distance of about $100 \mu \mathrm{m}$ from the scaffold outer surface (187), similar to a 2D culture. In these conditions, cells are subjected to different oxygen and nutrient concentrations across the scaffold, leading to the formation by the outer cell layer of a tissue capsule in the periphery of the scaffold, further limiting penetration of culture medium inside the construct (176, 188). More generally, the composition of the culture medium, including the availability of nutrients and the removal of waste products (e.g $\mathrm{CO}_{2}$, lactic acid, ammonia and products generated by oxidative stress), as well as the rate of exchange between the bulk medium and the construct interior are key parameters for 3D cell culture in vitro (4). Both parameters depend on the scaffold mass transfer properties (internal pore architecture discussed in section 2.3) and the culturing schemes (e.g. static vs perfused). As stated in introduction to this section, the perfusion bioreactor systems are currently unrivalled in terms of performance (e.g. cells activity and uniformity within the interior of the scaffold $(176,189$, 190). On the condition that the flow goes entirely through the scaffold and not around the edges, these systems allows an accurate control of the perfusion modalities of seeded cells (e.g. constant vs pulsatile) as well as their mechanical stimulation (see section 4.2), with the final aim to modulate stem cell fate (maintenance or differentiation) $(4,178)$.

Finally, another advantage of perfusion bioreactor is the monitoring of crucial parameters like oxygen using invasive (embedded) or non-invasive (non-contact) sensing probes (191). 
These monitoring tools/probes can also be used to follow the bone remodelling process as performed by Papadimitropoulos et al (see section 3.2) (166).

\subsection{Control of the mechanical stresses}

\subsubsection{Mechanical bone environment}

In vivo, it is well known that bone remodelling is induced and controlled by endogenous and exogenous factors (192-194). Dynamic mechanical stresses are osteogenic within a range of load intensities; beyond and below this range tissue responses are different $(195,196)$. In weight bearing bone, individual cells are not subjected to a single force. Multiple physical signals are generated simultaneously and sensed/integrated by the cells through their membrane, cytoskeleton, focal points, etc. (Fig. 3). Consequently, there is no single parameter in the mechanical environment that reliably predicts bone remodelling in vivo or under experimental conditions (197).

It is assumed that in vivo mechanical stimuli are mainly transmitted to bone cells through shear stress, that is to say forces whose vector is parallel to the cell surface (198). Bone tissue includes a significant fraction of interstitial fluid surrounding all cells. Movements of this fluid are induced by two different processes: an "internal" one, which is the differential pressure within the circulatory system $(199,200)$, and an "external" one consisting in the mechanical loads applied to the skeleton (201). Whenever a mechanical load is applied to bone, interstitial fluid is forced out of the areas of high compressive deformation, and flows back when the load is removed. Thus, the fluid flow generates an oscillating shear stress to which individual bone cells, and more especially the osteocytes, are sensitive (154).

The different forces exerted on cells are integrated via several extracellular mechanosensor like integrins and associated proteins (203), ion channels (204), connexin (205), primary cilia 
(206) and the actin cytoskeleton (207). These sensors take part in a set of cellular mechanisms that convert mechanical stimuli into biochemical signals (208) leading in changes of whole tissue metabolism (Fig. 3).

In 3D models, many mechanical stresses can be generated and studied such as tension, torsion and different combinations of these. In fundamental bone in vitro models, two types of mechanical stresses are mostly studied: loading stress resulting from mechanical solicitation, and shear stress imposed by fluid movement from the perfusion and/or the scaffold deformation (27).

Anyway, the control of these stresses is crucial to understand the transduction of mechanical signals by the bone cells or guide their fate.

\subsubsection{Fluid flow effects}

a) Shear stress in perfusion bioreactor

In addition to overcoming poor nutrient and waste exchange associated with static culture conditions $(188,209)$, culture in a flow perfusion bioreactor provides a convenient way to mechanically stimulate cells seeded in the scaffold through fluid shear stress $(198,210)$. Indeed, it was proved in numerous 2D in vitro studies that cells involved in bone tissue remodeling are sensitive to shear stress (211-213). In scaffolds, fluid flow (shear stress) has been also shown to enhance bone formation activity of osteoblasts (214-216) and stimulate the expression of bone-specific genes (217). An unidirectional steady flow, commonly used in clinical studies $(214,215,218)$, has been shown to have many biological effects on bone marrow stromal cells seeded in scaffolds, such as an enhancement of osteogenic differentiation (219) and an increased production of mineralized matrix $(214,220)$. However, since bone cells are mainly stimulated in vivo via dynamic (intermittent) mechanical loading 
$(221,222)$, this dynamic regime is likely to be crucial for stimulating bone formation and enhancing the quality of bone tissue laid by osteoblast (223). Other studies revealed a favorable effect on bone tissue formation of dynamic unidirectional flow (224) or oscillatory fluid flow $(170,225)$. Lastly, a recent study showed that sequential application of steady (for 2 weeks) and dynamic (for 3 weeks) fluid flow promotes bone formation by human adipose stem cells isolated from fat tissue and cultivated on porous silk fibroin scaffolds (226).

These results suggest that there is a cellular mechanism detecting and responding to the level and duration of shear stress induced by fluid flow. The level of shear stress experienced by cells cultured in a flow perfusion system varies with the flow rate. The local shear stress felt by individual cells will thus depend on the flow rate used throughout the perfusionseeding $(172,227)$, as well as the scaffold architecture (see section 2.3$)$. It remains unclear which flow profile is optimal for stimulating osteoblasts cultivated in a scaffold, and how it will regulates their activity and sensitivity. Such evaluation can be done using predictive tools (computational fluid dynamics technology $(228,229)$ ).

b) Biologically relevant shear stress

Most culture systems and bioreactors are not yet optimized on a mechanical point of view (mechanical stimuli generation). In the design of the perfusion bioreactors (3D in vitro studies), parameters, such as rate of perfusion, flow design (unidirectional, oscillatory, intermittent, etc.) and scaffold architecture have often been determined through trial-anderror $(54,230)$. Such empirical methods do not guarantee that these parameters are optimized. But computational tools are now available to determine the optimal values of these parameters. In order to improve the mechanostimulation of cells in bioreactors, it is 
first necessary to determine which levels of shear stress are relevant, and secondly to be able to evaluate the shear stress levels on scaffolds surfaces.

- Effective levels of shear stress in 2D cultures

It is relevant to wonder about the levels of shear stress that provide the best stimulation in bone cell function. A first value of reference was given by Weinbaum et al. in 1994 (231) through a model based on Biot's porous media theory, which is used to relate the loads applied to bone to the flow of canalicular interstitial fluid. The model predicts that the flow of physiological fluid induces shear stresses in the range of 0.8 to $3 \mathrm{~Pa}$ when bones are submitted to physiological loadings.

Many research teams analyzed experimentally the effect of shear stress on bone cell activity. To control the shear stress applied, parallel-plate flow chambers were developed and used in vitro with several types of cells and several shear stress regimens (e.g. frequency, time). A selection of the most relevant results is presented in Table 1. In these 2D experiments, shear stress levels between 0.1 and 2 Pa caused positive effects on cells such as release of nitric oxide and PGE2, phosphorylation of proteins ERK1/2 and p38, as well as up-regulation of the expression of some genes related to mechanotransduction and osteoblastic differentiation.

- Levels of shear stress in 3D, numerical simulation and confrontation with 2D values Scaffolds used for bone tissue engineering applications provide, by definition, a 3D structure with generally complex geometries. It is then impossible to control and homogenise the levels of shear stress experienced by cells in such structure. But some numerical methods were developed to evaluate these levels. Nowadays, numerical simulation is very widely used by researchers to simulate mechanical and/or biological environment experienced by cells seeded in scaffolds, to become a crucial research field. For an extensive review of 
current simulation techniques and strategies for dynamic bone tissue engineering in bioreactors we recommend a recent review by Vetsch et al. (239). Several research teams investigated the levels of flow-induced shear stress in their own system (i.e. bioreactor and scaffold (240-242)). A first step of modeling is generally achieved by analyzing the scaffold through micro-computed tomography in order to reconstruct its 3D architecture numerically. The reconstructed geometry of the scaffold can then be implemented in numerical simulations. Computational fluid dynamics methods for fluid simulation are used, such as Lattice Boltzmann $(240,243)$, finite volume $(70,241,244)$ or finite element methods $(71,245,246)$. Boundary conditions are implemented to reproduce the real fluid circulation. Then, calculation enables to determine the fluid velocity and the wall shear stress in the scaffolds. The shear stress levels calculated under certain hypotheses are listed in Table 2. We would like to emphasize that due to the highly randomized internal pore structure of the scaffolds used for these experiments, the shear stress distribution is very heterogeneous and we should retain the order of magnitude rather than the values themselves. It is very interesting to note that the calculated shear stress levels are in the range of 0.04 to $40 \mathrm{mPa}$ with boundary conditions of the numerical models representing the experimental conditions. These values are two to three orders of magnitude lower than the values reported in the 2D experimental studies (Table 1). This gap has been reported and explained in several works $(247,248)$. When cells are seeded in highly porous scaffolds, approximately $75 \%$ of them display a "bridging" morphology (i.e. they are suspended cells, as observed in Fig. $1 \mathrm{C}$ ), in contrast to the "flat" 2D morphology (i.e. in which cells lay flat on the substrate) (247). Even if this proportion could vary depending on internal pore architecture and cell type, these "bridging" cells exist and experience high levels of deformation compared to the "flat" cells; up to 500 times higher for the same flow configuration. This is very probably why 
the osteogenic responses can be observed at lower levels of wall shear stress in scaffold structures containing mainly bridging cells than in 2D culture experiments or in other types of bioreactors where cells are mainly flatly attached.

\subsubsection{Effects of mechanical loading}

While shear stress has been extensively used to mechanically stimulate cells in 3D, little has been done on cell response induced by compression forces in vitro.

Specially designed culture chambers are necessary to apply external mechanical signals combining shear and loading stresses (64, 109, 249, 250) (Fig. 2 A). This type of chamber makes possible to mimic in vitro the skeletal effects of physical activity. Mechanical loads generate substrate deformations inducing in parallel fluid flow shear stress (media movement within the scaffold). Both are more or less intense depending on the properties of the scaffold (see section 2). These deformations are experienced by the cells, through the $\mathrm{ECM}$ or directly through changes in cell shape or intercellular distances. Substrate elongation or compression can directly modify extracellular gradients, cell-cell communication or local concentrations of secreted ligands (251).

Globally, bioreactor systems designed for applying mechanical loading have shown beneficial effects of mechanical load on proliferation, osteogenic differentiation and matrix formation (Table 3). Specifically, it has been shown that compressive strains of approximately $10 \%$ (amounting to a stress of about $12 \mathrm{kPa}$ ) are osteogenic (Table 3). Other bioreactors (prototypes) have been designed and technically validated but have not been yet used in routine for biological evaluations $(255,256)$. Some of the bioreactors listed in Table $\mathbf{3}$ are not perfused. This technical restriction limits their experimental applications due first to the negative points inherent in the nature of the unperfused systems and especially static 
cultures (see section 4.1), and second to the impossibility to combine the effects of both compression and perfusion.

Lastly, all these studies are currently done with osteoblast-like cells in order to determine the effect of mechanical forces on bone formation. The next step will be to study their effects on bone resorption using (pre)osteoclasts with the ultimate goal to co-cultivate either or both cell types with the bone mechanosensor, the osteocyte.

\section{PERSPECTIVES IN 3D IMAGING}

As the field of 3D tissue engineering progresses there is a growing need for non-invasive, label-free imaging technologies for detailed analysis of the inside of the scaffolds, with high resolution and real-time observation capabilities throughout the culture period. Two on-line imaging systems able to monitor the 3D morphological structure of the mineralized and unmineralized fractions of the cultures will be presented: Optical Coherence Tomography (OCT) and the micro/nano tomography.

Operating under a principle similar to ultrasound imaging, with the exception that it measures delays in backscattered light instead of sound, OCT uses light in the near infrared part of the spectrum. OCT yields 3D tomographic images of biological tissues with a resolution of a few micrometres. This non-invasive, non-ionising method has been recently used for imaging a fixed human femoral trabecular bone sample (257). Without any staining, the lamellar structure of trabeculae and the cells in the marrow were visible, albeit with a penetration depth limited approximately to $1 \mathrm{~mm}(258,259)$. To improve the capabilities of OCT several extensions have been proposed including polarization, phase and spectrally resolved OCT. Spectroscopic Optical Coherence Tomography (SOCT) is sensitive to both chromophores and structural changes of the tissue, which alter the incident light spectrum. 
The performance of such approach has been tested for contrast enhancement in bovine osteo-articular cartilage. Specifically, when the tissue is loaded the different layers of cartilage get enhanced contrast due to optical clearing. During cartilage compression, water is expelled out of the tissue and the change of the collagen fibre composition in the different zones could be a reasonable explanation for the enhanced contrast due to spectroscopic features (260). Whether some interesting results on structural investigation of native bone have been gathered, the applications of these techniques to in vitro tissue-engineered bone are not yet very numerous at present (260).

Micro-computed tomography (micro-CT) is often used to characterise scaffolds and bone growth in 3D (261). Micro-CT uses X-rays and provides a non-destructive 3D image of the interior of a sample, regardless of size, with a resolution ranging from 1 to $100 \mu \mathrm{m}$. The combination of micro-CT and recently developed microdiffraction, $\mathrm{x}$-ray techniques have facilitated qualitative and quantitative characterisation of dense scaffolds, as well as a 3D evaluation of the rate of bone growth in engineered tissue (262). More specifically X-ray microdiffraction provides information at the atomic scale, i.e. at the nanometre level, of both mineral and organic phases. Wide angle X-ray scattering (WAXS) informs mainly about the crystallographic structure and texture of the samples, while Small angle X-ray scattering (SAXS) is more about size, shape and orientation of both the mineral crystals and collagen fibrils (262) which compose the sample. Synchrotron radiation tomography (SRT) has enabled acquisition of even better results in terms of spatial resolution (under $1 \mu \mathrm{m}$ ) and signal/noise ratio (263). In addition to revealing the architecture of the sample, SRT also provides information about composition (i.e. the 3D distribution and degree of mineralisation) (264). However, equipment to perform this technique is only available in a few research centres around the world. 
Micro-CT and SRT techniques allow visualisation and quantification of mineralised structures, including the possibility to investigate the influence of scaffold features, such as the internal pore architecture (e.g. size, distribution) with regard to the growth of bone within the scaffold. Unfortunately, this method does not yet allow to visualise the cells. "Xray synchrotron radiation pseudo-holotomography" was recently developed to visualise soft tissue and microvascular networks in 3D without the use of contrasting agents. The method is based on micro-CT and conventional holotomography techniques and was used to obtain quantitative structural data on a bioceramic/MSC composite implanted in mice for 24 weeks (265).

If major improvements in mapping and monitoring 3D tissue growth have been achieved, progress is still required in quantifying changes in depth with the appropriate resolution for cellular analysis. Further bioreactor should be designed to allow for in situ imaging with the help of optical and/or x-ray transparent culture chambers or by placing transparent windows on the chamber walls.

\section{CONCLUSIONS}

Traditional cell culture, i.e. two-dimensional (2D), is unable to reproduce the tissue properties observed in organs (3D). Moreover, natural tissues, especially in weight-bearing organs such as bone, are subjected to mechanical stresses which are major regulating factors for cell fate. In vitro 3D culture models seem to be an effective solution to better understand the different aspects of cell function and bone remodeling in systems less complex than in vivo models. Create bone in vitro, using tissue engineering concepts, can be a somewhat elusive vision given the complexity of this tissue, encompassing spatial and temporal interactions between many types of components (e.g. cells, ECM, substrate, soluble factors). 
However, new experimental, manufacturing, characterization and computational tools help to design a controlled environment more and more efficient to regulate cell fate. Even, if the influence of material properties, such as stiffness, permeability, or composition, in orchestrating cellular events is still poorly understood, the "design strategy" associated to an extensive scaffold characterization is a consistent approach to define relevant scaffold design/features. Perfusion based bioreactors have been shown to optimize cell culture in 3D with full and standardized control of cell environment (e.g. scaffold architecture and physico-chemical properties, medium composition and delivery, mechanical stimuli) (Fig. 4). This new way to cultivate cells requires a redefinition of standard cell culture methods applied in two dimensions (2D) starting with cell seeding techniques and growth conditions (e.g. $\mathrm{O}_{2}$ levels). The development and follow-up of such controlled and constrained systems also calls for a multidisciplinary knowledge, relying on close collaboration between researchers and engineers specialising in biology (molecular and cellular), chemistry, physics and mechanics (of solid and fluid matter).

Development of advanced methods for real-time analysis is required to characterize and monitor the physical and chemical environment of the cells and their interactions with the construct. No 3D in vitro culture strategy can provide a "complete" model of bone tissue (i.e. its different components). For this reason, rather than attempting to build the perfect general 3D bone model, research should focus on developing specific tools for the purpose of solving one or several well thought biological questions. To conclude, this approach will serve basic research, provide a test bench for the development of active molecules targeting bone cell as well as therapeutic applications (implantations). The trial-and-error approach mostly used to validate scaffold/biomaterial properties for implantation (e.g. composition, 
architecture) or implant manufacturing (e.g. rhBMP2 dose, preculture in bioreactor before implantation) could be guided by results obtained in these in vitro 3D culture systems.

\section{Aknowledgements}

The study was partially funded by the European Space Agency (Microgravity Application Program, MAP “ERISTO” (European Research In Space and Terrestrial Osteoporosis, contract number 14232/00/NL/SH) and the French Ministry of Research (fellowship given to Guenaelle Bouet).

\section{Author Disclosure Statement}

No competing financial interests exist. 


\section{$\underline{\text { References }}$}

1. Langer, R., and Vacanti, J.P. Tissue engineering. Science 260, 920, 1993.

2. Hay, E.D. Cell Biology of Extracellular Matrix. 2nd Edition ed. New York Plenum Press.; 1991.

3. Burridge, K., and Tsukita, S. Editorial overview: Cell-to-cell contact and extracellular matrix. Current Opinion in Cell Biology 13, 525, 2001.

4. Szpalski, C., Sagebin, F., Barbaro, M., and Warren, S.M. The influence of environmental factors on bone tissue engineering. J Biomed Mater Res B Appl Biomater 101, 663, 2013.

5. Gardel, L.S., Serra, L.A., Reis, R.L., and Gomes, M.E. Use of perfusion bioreactors and large animal models for long bone tissue engineering. Tissue Eng Part B Rev 20, 126, 2014.

6. Cukierman, E., Pankov, R., Stevens, D.R., and Yamada, K.M. Taking cell-matrix adhesions to the third dimension. Science 294, 1708, 2001.

7. Cukierman, E., Pankov, R., and Yamada, K.M. Cell interactions with three-dimensional matrices. Curr Opin Cell Biol 14, 633, 2002.

8. Ishii, I., Tomizawa, A., Kawachi, H., Suzuki, T., Kotani, A., Koshushi, I., Itoh, H., Morisaki, N., Bujo, H., Saito, Y., Ohmori, S., and Kitada, M. Histological and functional analysis of vascular smooth muscle cells in a novel culture system with honeycomb-like structure. Atherosclerosis 158, 377, 2001.

9. Elsdale, T., and Bard, J. Collagen substrata for studies on cell behavior. J Cell Biol 54, 626, 1972.

10. McCoy, R.J., and O'Brien, F.J. Influence of shear stress in perfusion bioreactor cultures for the development of three-dimensional bone tissue constructs: a review. Tissue Eng Part B Rev 16, 587, 2010.

11. Liu, C., Abedian, R., Meister, R., Haasper, C., Hurschler, C., Krettek, C., von Lewinski, G., and Jagodzinski, $\mathrm{M}$. Influence of perfusion and compression on the proliferation and differentiation of bone mesenchymal stromal cells seeded on polyurethane scaffolds. Biomaterials 33, 1052, 2012.

12. Sittichockechaiwut, A., Scutt, A.M., Ryan, A.J., Bonewald, L.F., and Reilly, G.C. Use of rapidly mineralising osteoblasts and short periods of mechanical loading to accelerate matrix maturation in 3D scaffolds. Bone 44, 822, 2009.

13. Lutolf, M.P., Gilbert, P.M., and Blau, H.M. Designing materials to direct stem-cell fate. Nature 462, 433, 2009.

14. Owen, S.C., and Shoichet, M.S. Design of three-dimensional biomimetic scaffolds. Journal of Biomedical Materials Research Part A 94A, 1321, 2010.

15. Schmeichel, K.L., and Bissell, M.J. Modeling tissue-specific signaling and organ function in three dimensions. Journal of cell science 116, 2377, 2003.

16. Chitcholtan, K., Asselin, E., Parent, S., Sykes, P.H., and Evans, J.J. Differences in growth properties of endometrial cancer in three dimensional (3D) culture and 2D cell monolayer. Exp Cell Res 319, 75, 2013.

17. Lukashev, M.E., and Werb, Z. ECM signalling: orchestrating cell behaviour and misbehaviour. Trends in Cell Biology 8, 437, 1998.

18. Zhao, W., Li, X., Liu, X., Zhang, N., and Wen, X. Effects of substrate stiffness on adipogenic and osteogenic differentiation of human mesenchymal stem cells. Materials science \& engineering $C$, Materials for biological applications 40, 316, 2014.

19. Tandon, N., Marolt, D., Cimetta, E., and Vunjak-Novakovic, G. Bioreactor engineering of stem cell environments. Biotechnology advances 31, 1020, 2013.

20. van Griensven, M., Diederichs, S., Roeker, S., Boehm, S., Peterbauer, A., Wolbank, S., Riechers, D., Stahl, F., and Kasper, C. Mechanical Strain Using 2D and 3D Bioreactors Induces Osteogenesis: Implications for Bone Tissue Engineering. In: Kasper D.C., Griensven P.M.v., Pörtner D.R., eds. Bioreactor Systems for Tissue Engineering. Berlin: Springer Berlin Heidelberg; 2009. pp. 95.

21. Heljak, M.K., Swieszkowski, W., Lam, C.X.F., Hutmacher, D.W., and Kurzydlowski, K.J. Evolutionary design of bone scaffolds with reference to material selection. Int J Numer Meth Bio 28, 789, 2012. 
22. Boyan, B.D., Hummert, T.W., Dean, D.D., and Schwartz, Z. Role of material surfaces in regulating bone and cartilage cell response. Biomaterials 17, 137, 1996.

23. Samavedi, S., Whittington, A.R., and Goldstein, A.S. Calcium phosphate ceramics in bone tissue engineering: a review of properties and their influence on cell behavior. Acta Biomater 9, 8037, 2013. 24. Harrison, R.H., St-Pierre, J.P., and Stevens, M.M. Tissue engineering and regenerative medicine: a year in review. Tissue Eng Part B Rev 20, 1, 2014.

25. Melchels, F.P.W., Barradas, A.M.C., van Blitterswijk, C.A., de Boer, J., Feijen, J., and Grijpma, D.W. Effects of the architecture of tissue engineering scaffolds on cell seeding and culturing. Acta Biomaterialia 6, 4208, 2010.

26. Salerno, A., Guarnieri, D., lannone, M., Zeppetelli, S., and Netti, P.A. Effect of Micro- and Macroporosity of Bone Tissue Three-Dimensional-Poly(epsilon-Caprolactone) Scaffold on Human Mesenchymal Stem Cells Invasion, Proliferation, and Differentiation In Vitro. Tissue Eng Pt A 16, 2661, 2010.

27. Grayson, W.L., Vunjak-Novakovic, G., and Obradovic, B. Bioreactors in tissue engineering. In: Obradović B., ed. Cell and Tissue Engineering. Belgrade, Serbia: Springer Berlin Heidelberg; 2012. pp. 217.

28. Lam, C.X., Savalani, M.M., Teoh, S.H., and Hutmacher, D.W. Dynamics of in vitro polymer degradation of polycaprolactone-based scaffolds: accelerated versus simulated physiological conditions. Biomedical materials 3, 034108, 2008.

29. Pecqueux, F., Tancret, F., Payraudeau, N., and Bouler, J.M. Influence of microporosity and macroporosity on the mechanical properties of biphasic calcium phosphate bioceramics: Modelling and experiment. Journal of the European Ceramic Society 30, 819, 2010.

30. Bose, S., Roy, M., and Bandyopadhyay, A. Recent advances in bone tissue engineering scaffolds. Trends Biotechnol 30, 546, 2012.

31. Levengood, S.K.L., Polak, S.J., Wheeler, M.B., Maki, A.J., Clark, S.G., Jamison, R.D., and Johnson, A.J.W. Multiscale osteointegration as a new paradigm for the design of calcium phosphate scaffolds for bone regeneration. Biomaterials 31, 3552, 2010.

32. Saiz, E., Zimmermann, E.A., Lee, J.S., Wegst, U.G.K., and Tomsia, A.P. Perspectives on the role of nanotechnology in bone tissue engineering. Dent Mater 29, 103, 2013.

33. Unadkat, H.V., Hulsman, M., Cornelissen, K., Papenburg, B.J., Truckenmuller, R.K., Post, G.F., Uetz, M., Reinders, M.J.T., Stamatialis, D., van Blitterswijk, C.A., and de Boer, J. An algorithm-based topographical biomaterials library to instruct cell fate. Proceedings of the National Academy of Sciences of the United States of America 108, 16565, 2011.

34. Woodard, J.R., Hilldore, A.J., Lan, S.K., Park, C.J., Morgan, A.W., Eurell, J.A.C., Clark, S.G., Wheeler, M.B., Jamison, R.D., and Johnson, A.J.W. The mechanical properties and osteoconductivity of hydroxyapatite bone scaffolds with multi-scale porosity. Biomaterials 28, 45, 2007.

35. Chan, O., Coathup, M.J., Nesbitt, A., Ho, C.Y., Hing, K.A., Buckland, T., Campion, C., and Blunn, G.W. The effects of microporosity on osteoinduction of calcium phosphate bone graft substitute biomaterials. Acta Biomaterialia 8, 2788, 2012.

36. Dalby, M.J., Gadegaard, N., Tare, R., Andar, A., Riehle, M.O., Herzyk, P., Wilkinson, C.D.W., and Oreffo, R.O.C. The control of human mesenchymal cell differentiation using nanoscale symmetry and disorder. Nat Mater 6, 997, 2007.

37. Deligianni, D.D., Katsala, N., Ladas, S., Sotiropoulou, D., Amedee, J., and Missirlis, Y.F. Effect of surface roughness of the titanium alloy Ti-6Al-4V on human bone marrow cell response and on protein adsorption. Biomaterials 22, 1241, 2001.

38. Li, B., Liao, X.L., Zheng, L., Zhu, X.D., Wang, Z., Fan, H.S., and Zhang, X.D. Effect of nanostructure on osteoinduction of porous biphasic calcium phosphate ceramics. Acta Biomaterialia 8, 3794, 2012.

39. Habibovic, P., Yuan, H.P., van der Valk, C.M., Meijer, G., van Blitterswijk, C.A., and de Groot, K. 3D microenvironment as essential element for osteoinduction by biomaterials. Biomaterials 26, 3565, 2005.

40. Boyan, B.D., Lohmann, C.H., Dean, D.D., Sylvia, V.L., Cochran, D.L., and Schwartz, Z. Mechanisms involved in osteoblast response to implant surface morphology. Ann Rev Mater Res 31, 357, 2001. 
41. Curtis, A., and Wilkinson, C. Topographical control of cells. Biomaterials 18, 1573, 1997.

42. Challis, V.J., Roberts, A.P., Grotowski, J.F., Zhang, L.-C., and Sercombe, T.B. Prototypes for Bone Implant Scaffolds Designed via Topology Optimization and Manufactured by Solid Freeform Fabrication. Advanced Engineering Materials 12, 1106, 2010.

43. Marcos-Campos, I., Marolt, D., Petridis, P., Bhumiratana, S., Schmidt, D., and Vunjak-Novakovic, G. Bone scaffold architecture modulates the development of mineralized bone matrix by human embryonic stem cells. Biomaterials 33, 8329, 2012.

44. Rouwkema, J., Rivron, N.C., and van Blitterswijk, C.A. Vascularization in tissue engineering. Trends Biotechnol 26, 434, 2008.

45. Rumpler, M., Woesz, A., Dunlop, J.W., van Dongen, J.T., and Fratzl, P. The effect of geometry on three-dimensional tissue growth. Journal of the Royal Society, Interface / the Royal Society 5, 1173, 2008.

46. Saito, E., Liu, Y., Migneco, F., and Hollister, S.J. Strut size and surface area effects on long-term in vivo degradation in computer designed poly(L-lactic acid) three-dimensional porous scaffolds. Acta Biomater 8, 2568, 2012.

47. Hannink, G., and Arts, J.J. Bioresorbability, porosity and mechanical strength of bone substitutes: what is optimal for bone regeneration? Injury 42 Suppl 2, S22, 2011.

48. Almeida, C.R., Serra, T., Oliveira, M.I., Planell, J.A., Barbosa, M.A., and Navarro, M. Impact of 3-D printed PLA- and chitosan-based scaffolds on human monocyte/macrophage responses: unraveling the effect of 3-D structures on inflammation. Acta Biomater 10, 613, 2014.

49. Olivares, A.L., Marshal, E., Planell, J.A., and Lacroix, D. Finite element study of scaffold architecture design and culture conditions for tissue engineering. Biomaterials 30, 6142, 2009.

50. Melchels, F.P., Tonnarelli, B., Olivares, A.L., Martin, I., Lacroix, D., Feijen, J., Wendt, D.J., and Grijpma, D.W. The influence of the scaffold design on the distribution of adhering cells after perfusion cell seeding. Biomaterials 32, 2878, 2011.

51. Kapfer, S.C., Hyde, S.T., Mecke, K., Arns, C.H., and Schroder-Turk, G.E. Minimal surface scaffold designs for tissue engineering. Biomaterials 32, 6875, 2011.

52. McBeath, R., Pirone, D.M., Nelson, C.M., Bhadriraju, K., and Chen, C.S. Cell shape, cytoskeletal tension, and RhoA regulate stem cell lineage commitment. Dev Cell 6, 483, 2004.

53. Kim, J., and Ma, T. Bioreactor Strategy in Bone Tissue Engineering: Pre-Culture and Osteogenic Differentiation Under Two Flow Configurations. Tissue Eng Pt A 18, 2354, 2012.

54. Mastrogiacomo, M., Scaglione, S., Martinetti, R., Dolcini, L., Beltrame, F., Cancedda, R., and Quarto, R. Role of scaffold internal structure on in vivo bone formation in macroporous calcium phosphate bioceramics. Biomaterials 27, 3230, 2006.

55. Silva, M.M.C.G., Cyster, L.A., Barry, J.J.A., Yang, X.B., Oreffo, R.O.C., Grant, D.M., Scotchford, C.A., Howdle, S.M., Shakesheff, K.M., and Rose, F.R.A.J. The effect of anisotropic architecture on cell and tissue infiltration into tissue engineering scaffolds. Biomaterials 27, 5909, 2006.

56. Roosa, S.M.M., Kemppainen, J.M., Moffitt, E.N., Krebsbach, P.H., and Hollister, S.J. The pore size of polycaprolactone scaffolds has limited influence on bone regeneration in an in vivo model. Journal of Biomedical Materials Research Part A 92A, 359, 2010.

57. von Doernberg, M.C., von Rechenberg, B., Bohner, M., Grunenfelder, S., van Lenthe, G.H., Muller, R., Gasser, B., Mathys, R., Baroud, G., and Auer, J. In vivo behavior of calcium phosphate scaffolds with four different pore sizes. Biomaterials 27, 5186, 2006.

58. Bohner, M., Loosli, Y., Baroud, G., and Lacroix, D. Commentary: Deciphering the link between architecture and biological response of a bone graft substitute. Acta Biomater 7, 478, 2011.

59. Wilson, C.E., van Blitterswijk, C.A., Verbout, A.J., Dhert, W.J., and de Bruijn, J.D. Scaffolds with a standardized macro-architecture fabricated from several calcium phosphate ceramics using an indirect rapid prototyping technique. J Mater Sci Mater Med 22, 97, 2011.

60. Melchels, F.P.W., Domingos, M.A.N., Klein, T.J., Malda, J., Bartolo, P.J., and Hutmacher, D.W. Additive manufacturing of tissues and organs. Prog Polym Sci 37, 1079, 2012.

61. Liu, X., Smith, L.A., Hu, J., and Ma, P.X. Biomimetic nanofibrous gelatin/apatite composite scaffolds for bone tissue engineering. Biomaterials 30, 2252, 2009. 
62. Descamps, M., Duhoo, T., Monchau, F., Lu, J., Hardouin, P., Hornez, J.C., and Leriche, A. Manufacture of macroporous beta-tricalcium phosphate bioceramics. Journal of the European Ceramic Society 28, 149, 2008.

63. Teixeira, S., Fernandes, H., Leusink, A., van Blitterswijk, C., Ferraz, M.P., Monteiro, F.J., and de Boer, J. In vivo evaluation of highly macroporous ceramic scaffolds for bone tissue engineering. Journal of Biomedical Materials Research Part A 93A, 567, 2010.

64. David, V., Guignandon, A., Martin, A., Malaval, L., Lafage-Proust, M.H., Rattner, A., Mann, V., Noble, B., Jones, D.B., and Vico, L. Ex Vivo bone formation in bovine trabecular bone cultured in a dynamic 3D bioreactor is enhanced by compressive mechanical strain. Tissue Eng Part A 14, 117, 2008.

65. Sanchez-Salcedo, S., Werner, J., and Vallet-Regi, M. Hierarchical pore structure of calcium phosphate scaffolds by a combination of gel-casting and multiple tape-casting methods. Acta Biomaterialia 4, 913, 2008.

66. Wilson, C.E., van Blitterswijk, C.A., Verbout, A.J., Dhert, W.J.A., and de Bruijn, J.D. Scaffolds with a standardized macro-architecture fabricated from several calcium phosphate ceramics using an indirect rapid prototyping technique. J Mater Sci-Mater M 22, 97, 2011.

67. Kumar, G., Tison, C.K., Chatterjee, K., Pine, P.S., McDaniel, J.H., Salit, M.L., Young, M.F., and Simon, C.G., Jr. The determination of stem cell fate by 3D scaffold structures through the control of cell shape. Biomaterials 32, 9188, 2011.

68. Oh, D.S., Kim, Y.J., Hong, M.-H., Han, M.-H., and Kim, K. Effect of capillary action on bone regeneration in micro-channeled ceramic scaffolds. Ceramics International 40, 9583, 2014.

69. Roohani-Esfahani, S.I., Dunstan, C.R., Li, J.J., Lu, Z., Davies, B., Pearce, S., Field, J., Williams, R., and Zreiqat, $\mathrm{H}$. Unique microstructural design of ceramic scaffolds for bone regeneration under load. Acta Biomater 9, 7014, 2013.

70. Cioffi, M., Kuffer, J., Strobel, S., Dubini, G., Martin, I., and Wendt, D. Computational evaluation of oxygen and shear stress distributions in 3D perfusion culture systems: macro-scale and microstructured models. J Biomech 41, 2918, 2008.

71. Milan, J.L., Planell, J.A., and Lacroix, D. Computational modelling of the mechanical environment of osteogenesis within a polylactic acid-calcium phosphate glass scaffold. Biomaterials 30, 4219, 2009.

72. ASTM. Standard F2792 - 12a "Terminology for Additive Manufacturing Technologies". ASTM International. West Conshohocken, PA, DOI: 10.1520/F2792-12A , www.astm.org.2012.

73. Munch, E., Franco, J., Deville, S., Hunger, P., Saiz, E., and Tomsia, A.P. Porous ceramic scaffolds with complex architectures. Jom-Us 60, 54, 2008.

74. Yoo, D. New paradigms in internal architecture design and freeform fabrication of tissue engineering porous scaffolds. Med Eng Phys 34, 762, 2012.

75. Giannitelli, S.M., Accoto, D., Trombetta, M., and Rainer, A. Current trends in the design of scaffolds for computer-aided tissue engineering. Acta Biomater 10, 580, 2014.

76. Mota, C., Puppi, D., Chiellini, F., and Chiellini, E. Additive manufacturing techniques for the production of tissue engineering constructs. J Tissue Eng Regen Med 2012.

77. Truscello, S., Kerckhofs, G., Van Bael, S., Pyka, G., Schrooten, J., and Van Oosterwyck, H. Prediction of permeability of regular scaffolds for skeletal tissue engineering: a combined computational and experimental study. Acta Biomater 8, 1648, 2012.

78. Bormann, T., Schulz, G., Deyhle, H., Beckmann, F., de Wild, M., Kuffer, J., Munch, C., Hoffmann, W., and Muller, B. Combining micro computed tomography and three-dimensional registration to evaluate local strains in shape memory scaffolds. Acta Biomater 10, 1024, 2014.

79. Wieding, J., Wolf, A., and Bader, R. Numerical optimization of open-porous bone scaffold structures to match the elastic properties of human cortical bone. J Mech Behav Biomed 37, 56, 2014.

80. Hollister, S.J., and Lin, C.Y. Computational design of tissue engineering scaffolds. Comput Method Appl M 196, 2991, 2007. 
81. Dias, M.R., Guedes, J.M., Flanagan, C.L., Hollister, S.J., and Fernandes, P.R. Optimization of scaffold design for bone tissue engineering: A computational and experimental study. Med Eng Phys 36, 448, 2014.

82. Bidan, C.M., Kommareddy, K.P., Rumpler, M., Kollmannsberger, P., Brechet, Y.J., Fratzl, P., and Dunlop, J.W. How linear tension converts to curvature: geometric control of bone tissue growth. PloS one 7, e36336, 2012.

83. Bidan, C.M., Kommareddy, K.P., Rumpler, M., Kollmannsberger, P., Fratzl, P., and Dunlop, J.W. Geometry as a factor for tissue growth: towards shape optimization of tissue engineering scaffolds. Advanced healthcare materials 2, 186, 2013.

84. Xu, M., Zhai, D., Chang, J., and Wu, C. In vitro assessment of three-dimensionally plotted nagelschmidtite bioceramic scaffolds with varied macropore morphologies. Acta Biomater 10, 463, 2014.

85. Schumacher, M., Deisinger, U., Detsch, R., and Ziegler, G. Indirect rapid prototyping of biphasic calcium phosphate scaffolds as bone substitutes: influence of phase composition, macroporosity and pore geometry on mechanical properties. J Mater Sci Mater Med 21, 3119, 2010.

86. Allori, A.C., Davidson, E.H., Reformat, D.D., Sailon, A.M., Freeman, J., Vaughan, A., Wootton, D., Clark, E., Ricci, J.L., and Warren, S.M. Design and validation of a dynamic cell-culture system for bone biology research and exogenous tissue-engineering applications. Journal of Tissue Engineering and Regenerative Medicine, n/a, 2013.

87. van Dijkhuizen-Radersma, R., Moroni, L., Apeldoorn, A.v., Zhang, Z., and Grijpma, D. Chapter 7 Degradable polymers for tissue engineering. In: Blitterswijk C.v., Thomsen P., Lindahl A., Hubbell J., Williams D.F., Cancedda R., et al., eds. Tissue engineering. Burlington: Academic Press; 2008. pp. 193. 88. Barrère, F., Ni, M., Habibovic, P., Ducheyne, P., and Groot, K.d. Chapter 8 - Degradation of bioceramics. In: Blitterswijk C.v., Thomsen P., Lindahl A., Hubbell J., Williams D.F., Cancedda R., et al., eds. Tissue engineering. Burlington: Academic Press; 2008. pp. 223.

89. Dorozhkin, S.V. Calcium Orthophosphates as Bioceramics: State of the Art. Journal of Functional Biomaterials 1, 22, 2010.

90. John, A., Varma, H.K., and Kumari, T.V. Surface reactivity of calcium phosphate based ceramics in a cell culture system. Journal of biomaterials applications 18, 63, 2003.

91. Detsch, R., Mayr, H., and Ziegler, G. Formation of osteoclast-like cells on HA and TCP ceramics. Acta Biomater 4, 139, 2008.

92. Spence, G., Patel, N., Brooks, R., Bonfield, W., and Rushton, N. Osteoclastogenesis on hydroxyapatite ceramics: the effect of carbonate substitution. J Biomed Mater Res A 92, 1292, 2010.

93. Barrere, F., van Blitterswijk, C.A., and de Groot, K. Bone regeneration: molecular and cellular interactions with calcium phosphate ceramics. International journal of nanomedicine 1, 317, 2006.

94. Shepherd, J., Shepherd, D., and Best, S. Substituted hydroxyapatites for bone repair. J Mater Sci: Mater Med 23, 2335, 2012.

95. Shrivats, A.R., McDermott, M.C., and Hollinger, J.O. Bone tissue engineering: state of the union. Drug discovery today 2014.

96. Zhang, N., and Kohn, D.H. Using polymeric materials to control stem cell behavior for tissue regeneration. Birth Defects Research Part C: Embryo Today: Reviews 96, 63, 2012.

97. Oh, S., Oh, N., Appleford, M., and Ong, J.L. Bioceramics for Tissue Engineering Applications-A Review. American Journal of Biochemistry and Biotechnology 2, 49, 2006.

98. Owen, S.C., and Shoichet, M.S. Design of three-dimensional biomimetic scaffolds. J Biomed Mater Res A 94, 1321, 2010.

99. Bonassar, L.J., and Vacanti, C.A. Tissue engineering: the first decade and beyond. J Cell Biochem Suppl 30-31, 297, 1998.

100. Engler, A.J., Sen, S., Sweeney, H.L., and Discher, D.E. Matrix elasticity directs stem cell lineage specification. Cell 126, 677, 2006.

101. Zouani, O.F., Kalisky, J., Ibarboure, E., and Durrieu, M.-C. Effect of BMP-2 from matrices of different stiffnesses for the modulation of stem cell fate. Biomaterials 34, 2157, 2013. 
102. Das, R.K., and Zouani, O.F. A review of the effects of the cell environment physicochemical nanoarchitecture on stem cell commitment. Biomaterials 35, 5278, 2014.

103. Hutmacher, D.W. Scaffolds in tissue engineering bone and cartilage. Biomaterials 21, 2529, 2000.

104. Boanini, E., Gazzano, M., and Bigi, A. Ionic substitutions in calcium phosphates synthesized at low temperature. Acta Biomaterialia 6, 1882, 2010.

105. Shepherd, J.H., and Best, S.M. Calcium Phosphate Scaffolds for Bone Repair. Jom-Us 63, 83, 2011.

106. Wu, S., Liu, X., Yeung, K.W.K., Liu, C., and Yang, X. Biomimetic porous scaffolds for bone tissue engineering. Materials Science and Engineering: R: Reports 80, 1, 2014.

107. Alvarez, K., and Nakajima, H. Metallic Scaffolds for Bone Regeneration. Materials 2, 790, 2009.

108. Newman, P., Minett, A., Ellis-Behnke, R., and Zreiqat, H. Carbon nanotubes: their potential and pitfalls for bone tissue regeneration and engineering. Nanomedicine : nanotechnology, biology, and medicine 9, 1139, 2013.

109. Bouet G., M.D., Cruel M., Laurent C., Vico L., Malaval L. Validation of a new three dimensional in vitro cell culture system for bone tissue engineering allowing mechanical stimulation. Acta Biomater Submitted.

110. Hing, K.A., Wilson, L.E., and Buckland, T. Comparative performance of three ceramic bone graft substitutes. Spine J 7, 475, 2007.

111. Soon, Y.-M., Shin, K.-H., Koh, Y.-H., Lee, J.-H., Choi, W.-Y., and Kim, H.-E. Fabrication and compressive strength of porous hydroxyapatite scaffolds with a functionally graded core/shell structure. Journal of the European Ceramic Society 31, 13, 2011.

112. Kumar, G., Waters, M.S., Farooque, T.M., Young, M.F., and Simon, C.G., Jr. Freeform fabricated scaffolds with roughened struts that enhance both stem cell proliferation and differentiation by controlling cell shape. Biomaterials 33, 4022, 2012.

113. Guth, K., Campion, C., Buckland, T., and Hing, K. Effects of serum protein on ionic exchange between culture medium and microporous hydroxyapatite and silicate-substituted hydroxyapatite. J Mater Sci: Mater Med 22, 2155, 2011.

114. Marchat, D., Bouët, G., Lueckgen, A., Zymelka, M., Malaval, L., Szenknect, S., Dacheux, N., Bernache-Assollant, D., and Chevalier, J. Physico-Chemical Characterization and In Vitro Biological Evaluation of Pure SiHA for Bone Tissue Engineering Application. Key Engineering Materials 529-530, 351, 2013.

115. Marchat, D., Zymelka, M., Coelho, C., Gremillard, L., Joly-Pottuz, L., Babonneau, F., Esnouf, C., Chevalier, J., and Bernache-Assollant, D. Accurate characterization of pure silicon-substituted hydroxyapatite powders synthesized by a new precipitation route. Acta Biomaterialia 2013.

116. Kartsogiannis, V., and Ng, K.W. Cell lines and primary cell cultures in the study of bone cell biology. Molecular and cellular endocrinology 228, 79, 2004.

117. Witkowski, J.A. Dr. Carrel's immortal cells. Medical history 24, 129, 1980.

118. Hayflick, L. Mortality and immortality at the cellular level. A review. Biochemistry Biokhimiia 62 , 1180, 1997.

119. Martin, T.J., Ingleton, P.M., Underwood, J.C., Michelangeli, V.P., Hunt, N.H., and Melick, R.A. Parathyroid hormone-responsive adenylate cyclase in induced transplantable osteogenic rat sarcoma. Nature 260, 436, 1976.

120. Kodama H. A., A.Y., Sudo H., Kasai S., Yamamoto S. Establishment of a clonal osteogenic cell line from newborn mouse calvaria. Jpn J Oral Biol 23, 899, 1981.

121. Harris, S.A., Enger, R.J., Riggs, B.L., and Spelsberg, T.C. Development and characterization of a conditionally immortalized human fetal osteoblastic cell line. J Bone Miner Res 10, 178, 1995.

122. Sudo, H., Kodama, H.A., Amagai, Y., Yamamoto, S., and Kasai, S. In vitro differentiation and calcification in a new clonal osteogenic cell line derived from newborn mouse calvaria. J Cell Biol 96, 191, 1983.

123. Chou, Y.F., Dunn, J.C., and Wu, B.M. In vitro response of MC3T3-E1 pre-osteoblasts within three-dimensional apatite-coated PLGA scaffolds. J Biomed Mater Res B Appl Biomater 75, 81, 2005. 
124. Bonewald, L.F., Harris, S.E., Rosser, J., Dallas, M.R., Dallas, S.L., Camacho, N.P., Boyan, B., and Boskey, A. von Kossa staining alone is not sufficient to confirm that mineralization in vitro represents bone formation. Calcif Tissue Int 72, 537, 2003.

125. Saldana, L., Bensiamar, F., Bore, A., and Vilaboa, N. In search of representative models of human bone-forming cells for cytocompatibility studies. Acta Biomater 7, 4210, 2011.

126. Andersen, T.L., Abdelgawad, M.E., Kristensen, H.B., Hauge, E.M., Rolighed, L., Bollerslev, J., Kjaersgaard-Andersen, P., and Delaisse, J.M. Understanding Coupling between Bone Resorption and Formation: Are Reversal Cells the Missing Link? Am J Pathol 183, 235, 2013.

127. Ayobian-Markazi, N., Fourootan, T., and Kharazifar, M.J. Comparison of cell viability and morphology of a human osteoblast-like cell line (SaOS-2) seeded on various bone substitute materials: An in vitro study. Dental research journal 9, 86, 2012.

128. Anselme, K., Ponche, A., and Bigerelle, M. Relative influence of surface topography and surface chemistry on cell response to bone implant materials. Part 2: biological aspects. Proceedings of the Institution of Mechanical Engineers Part H, Journal of engineering in medicine 224, 1487, 2010.

129. Ben-Ze'ev, A. The cytoskeleton in cancer cells. Biochimica et biophysica acta 780, 197, 1985.

130. Guck, J., Schinkinger, S., Lincoln, B., Wottawah, F., Ebert, S., Romeyke, M., Lenz, D., Erickson, H.M., Ananthakrishnan, R., Mitchell, D., Kas, J., Ulvick, S., and Bilby, C. Optical deformability as an inherent cell marker for testing malignant transformation and metastatic competence. Biophys $\mathrm{J}$ 88, 3689, 2005.

131. Czekanska, E.M., Stoddart, M.J., Richards, R.G., and Hayes, J.S. In search of an osteoblast cell model for in vitro research. Eur Cell Mater 24, 1, 2012.

132. Boudiffa, M., Wade-Gueye, N.M., Guignandon, A., Vanden-Bossche, A., Sabido, O., Aubin, J.E., Jurdic, P., Vico, L., Lafage-Proust, M.H., and Malaval, L. Bone sialoprotein deficiency impairs osteoclastogenesis and mineral resorption in vitro. J Bone Miner Res 25, 2393, 2010.

133. Bouleftour, W., Boudiffa, M., Wade-Gueye, N.M., Bouet, G., Cardelli, M., Laroche, N., VandenBossche, A., Thomas, M., Bonnelye, E., Aubin, J.E., Vico, L., Lafage-Proust, M.H., and Malaval, L. Skeletal Development of Mice Lacking Bone Sialoprotein (BSP) - Impairment of Long Bone Growth and Progressive Establishment of High Trabecular Bone Mass. PloS one 9, e95144, 2014.

134. Bellows, C.G., Aubin, J.E., Heersche, J.N., and Antosz, M.E. Mineralized bone nodules formed in vitro from enzymatically released rat calvaria cell populations. Calcif Tissue Int 38, 143, 1986.

135. Lind, M., Deleuran, B., Thestrup-Pedersen, K., Soballe, K., Eriksen, E.F., and Bunger, C. Chemotaxis of human osteoblasts. Effects of osteotropic growth factors. Apmis 103, 140, 1995.

136. Haynesworth, S.E., Goshima, J., Goldberg, V.M., and Caplan, A.I. Characterization of cells with osteogenic potential from human marrow. Bone 13, 81, 1992.

137. Delorme, B., Chateauvieux, S., and Charbord, P. The concept of mesenchymal stem cells. Regenerative medicine 1, 497, 2006.

138. Dell'Accio, F., De Bari, C., and Luyten, F.P. Microenvironment and phenotypic stability specify tissue formation by human articular cartilage-derived cells in vivo. Exp Cell Res 287, 16, 2003.

139. De Bari, C., Dell'Accio, F., Vanlauwe, J., Eyckmans, J., Khan, I.M., Archer, C.W., Jones, E.A., McGonagle, D., Mitsiadis, T.A., Pitzalis, C., and Luyten, F.P. Mesenchymal multipotency of adult human periosteal cells demonstrated by single-cell lineage analysis. Arthritis Rheum 54, 1209, 2006.

140. Sottile, V., Halleux, C., Bassilana, F., Keller, H., and Seuwen, K. Stem cell characteristics of human trabecular bone-derived cells. Bone 30, 699, 2002.

141. Zuk, P.A., Zhu, M., Mizuno, H., Huang, J., Futrell, J.W., Katz, A.J., Benhaim, P., Lorenz, H.P., and Hedrick, M.H. Multilineage cells from human adipose tissue: implications for cell-based therapies. Tissue Eng 7, 211, 2001.

142. Nagatomo, K., Komaki, M., Sekiya, I., Sakaguchi, Y., Noguchi, K., Oda, S., Muneta, T., and Ishikawa, I. Stem cell properties of human periodontal ligament cells. J Periodontal Res 41, 303, 2006. 143. Charbord, P., Livne, E., Gross, G., Haupl, T., Neves, N.M., Marie, P., Bianco, P., and Jorgensen, C. Human bone marrow mesenchymal stem cells: a systematic reappraisal via the genostem experience. Stem Cell Rev 7, 32. 
144. Bianco, P., Cao, X., Frenette, P.S., Mao, J.J., Robey, P.G., Simmons, P.J., and Wang, C.Y. The meaning, the sense and the significance: translating the science of mesenchymal stem cells into medicine. Nature medicine 19, 35, 2013.

145. Zaleskas, J.M., Kinner, B., Freyman, T.M., Yannas, I.V., Gibson, L.J., and Spector, M. Contractile forces generated by articular chondrocytes in collagen-glycosaminoglycan matrices. Biomaterials $\mathbf{2 5}$, 1299, 2004.

146. Froud, S.J. The development, benefits and disadvantages of serum-free media. Developments in biological standardization 99, 157, 1999.

147. Zheng, X., Baker, H., Hancock, W.S., Fawaz, F., McCaman, M., and Pungor, E., Jr. Proteomic analysis for the assessment of different lots of fetal bovine serum as a raw material for cell culture. Part IV. Application of proteomics to the manufacture of biological drugs. Biotechnol Prog 22, 1294, 2006.

148. Gong, Z., Calkins, G., Cheng, E.C., Krause, D., and Niklason, L.E. Influence of culture medium on smooth muscle cell differentiation from human bone marrow-derived mesenchymal stem cells. Tissue Eng Part A 15, 319, 2009.

149. Sun, S., Guo, Z., Xiao, X., Liu, B., Liu, X., Tang, P.H., and Mao, N. Isolation of mouse marrow mesenchymal progenitors by a novel and reliable method. Stem Cells 21, 527, 2003.

150. Kular, J., Tickner, J., Chim, S.M., and Xu, J. An overview of the regulation of bone remodelling at the cellular level. Clinical biochemistry 45, 863, 2012.

151. Tortelli, F., Pujic, N., Liu, Y., Laroche, N., Vico, L., and Cancedda, R. Osteoblast and osteoclast differentiation in an in vitro three-dimensional model of bone. Tissue Eng Part A 15, 2373, 2009.

152. Nakagawa, K., Abukawa, H., Shin, M.Y., Terai, H., Troulis, M.J., and Vacanti, J.P. Osteoclastogenesis on tissue-engineered bone. Tissue Eng 10, 93, 2004.

153. Bonewald, L.F. The amazing osteocyte. J Bone Miner Res 26, 229, 2011.

154. Dallas, S.L., Prideaux, M., and Bonewald, L.F. The osteocyte: an endocrine cell ... and more. Endocrine reviews 34, 658, 2013.

155. Birmingham, E., Niebur, G.L., McHugh, P.E., Shaw, G., Barry, F.P., and McNamara, L.M. Osteogenic differentiation of mesenchymal stem cells is regulated by osteocyte and osteoblast cells in a simplified bone niche. Eur Cell Mater 23, 13, 2012.

156. Heino, T.J., Hentunen, T.A., and Vaananen, H.K. Conditioned medium from osteocytes stimulates the proliferation of bone marrow mesenchymal stem cells and their differentiation into osteoblasts. Exp Cell Res 294, 458, 2004.

157. Zhao, S., Zhang, Y.K., Harris, S., Ahuja, S.S., and Bonewald, L.F. MLO-Y4 osteocyte-like cells support osteoclast formation and activation. J Bone Miner Res 17, 2068, 2002.

158. Heino, T.J., Kurata, K., Higaki, H., and Vaananen, H.K. Evidence for the role of osteocytes in the initiation of targeted remodeling. Technology and health care : official journal of the European Society for Engineering and Medicine 17, 49, 2009.

159. Vazquez M., E.B.A.J., Evans S., Ralphs J.R., Riccardi D., Mason D.J. In vitro 3D osteoblastosteocyte co-culture mechanical loading model. Osteoporos Int 23, 560, 2012.

160. Kulkarni, R.N., Bakker, A.D., Everts, V., and Klein-Nulend, J. Inhibition of osteoclastogenesis by mechanically loaded osteocytes: involvement of MEPE. Calcif Tissue Int 87, 461, 2010.

161. Taylor, A.F., Saunders, M.M., Shingle, D.L., Cimbala, J.M., Zhou, Z., and Donahue, H.J. Mechanically stimulated osteocytes regulate osteoblastic activity via gap junctions. Am J Physiol Cell Physiol 292, C545, 2007.

162. Villars, F., Guillotin, B., Amedee, T., Dutoya, S., Bordenave, L., Bareille, R., and Amedee, J. Effect of HUVEC on human osteoprogenitor cell differentiation needs heterotypic gap junction communication. Am J Physiol Cell Physiol 282, C775, 2002.

163. Meury, T., Verrier, S., and Alini, M. Human endothelial cells inhibit BMSC differentiation into mature osteoblasts in vitro by interfering with osterix expression. J Cell Biochem 98, 992, 2006.

164. Grellier, M., Bordenave, L., and Amedee, J. Cell-to-cell communication between osteogenic and endothelial lineages: implications for tissue engineering. Trends Biotechnol 27, 562, 2009. 
165. Grellier, M., Ferreira-Tojais, N., Bourget, C., Bareille, R., Guillemot, F., and Amedee, J. Role of vascular endothelial growth factor in the communication between human osteoprogenitors and endothelial cells. J Cell Biochem 106, 390, 2009.

166. Papadimitropoulos, A., Scherberich, A., Guven, S., Theilgaard, N., Crooijmans, H.J., Santini, F., Scheffler, K., Zallone, A., and Martin, I. A 3D in vitro bone organ model using human progenitor cells. Eur Cell Mater 21, 445.

167. Donnelly, E. Methods for assessing bone quality: a review. Clin Orthop Relat Res 469, 2128, 2011.

168. Holy, C.E., Shoichet, M.S., and Davies, J.E. Engineering three-dimensional bone tissue in vitro using biodegradable scaffolds: investigating initial cell-seeding density and culture period. J Biomed Mater Res 51, 376, 2000.

169. Dumas, V., Perrier, A., Malaval, L., Laroche, N., Guignandon, A., Vico, L., and Rattner, A. The effect of dual frequency cyclic compression on matrix deposition by osteoblast-like cells grown in 3D scaffolds and on modulation of VEGF variant expression. Biomaterials 30, 3279, 2009.

170. Du, D., Furukawa, K.S., and Ushida, T. 3D culture of osteoblast-like cells by unidirectional or oscillatory flow for bone tissue engineering. Biotechnol Bioeng 102, 1670, 2009.

171. Wendt, D., Marsano, A., Jakob, M., Heberer, M., and Martin, I. Oscillating perfusion of cell suspensions through three-dimensional scaffolds enhances cell seeding efficiency and uniformity. Biotechnol Bioeng 84, 205, 2003.

172. Alvarez-Barreto, J.F., Linehan, S.M., Shambaugh, R.L., and Sikavitsas, V.I. Flow perfusion improves seeding of tissue engineering scaffolds with different architectures. Ann Biomed Eng 35, 429, 2007.

173. Li, Y., Ma, T., Kniss, D.A., Lasky, L.C., and Yang, S.T. Effects of filtration seeding on cell density, spatial distribution, and proliferation in nonwoven fibrous matrices. Biotechnol Prog 17, 935, 2001.

174. Burg, K.J., Holder, W.D., Jr., Culberson, C.R., Beiler, R.J., Greene, K.G., Loebsack, A.B., Roland, W.D., Eiselt, P., Mooney, D.J., and Halberstadt, C.R. Comparative study of seeding methods for threedimensional polymeric scaffolds. J Biomed Mater Res 51, 642, 2000.

175. Vunjak-Novakovic, G., and Freed, L.E. Culture of organized cell communities. Adv Drug Deliv Rev 33, 15, 1998.

176. Goldstein, A.S., Juarez, T.M., Helmke, C.D., Gustin, M.C., and Mikos, A.G. Effect of convection on osteoblastic cell growth and function in biodegradable polymer foam scaffolds. Biomaterials 22, 1279, 2001.

177. Rauh, J., Milan, F., Gunther, K.P., and Stiehler, M. Bioreactor systems for bone tissue engineering. Tissue Eng Part B Rev 17, 263, 2011.

178. Yeatts, A.B., Choquette, D.T., and Fisher, J.P. Bioreactors to influence stem cell fate: augmentation of mesenchymal stem cell signaling pathways via dynamic culture systems. Biochimica et biophysica acta 1830, 2470, 2013.

179. Kellner, K., Liebsch, G., Klimant, I., Wolfbeis, O.S., Blunk, T., Schulz, M.B., and Gopferich, A. Determination of oxygen gradients in engineered tissue using a fluorescent sensor. Biotechnol Bioeng 80, 73, 2002.

180. Hermitte, F., Brunet de la Grange, P., Belloc, F., Praloran, V., and Ivanovic, Z. Very low $\mathrm{O} 2$ concentration (0.1\%) favors G0 return of dividing CD34+ cells. Stem cells 24, 65, 2006.

181. Ezashi, T., Das, P., and Roberts, R.M. Low $\mathrm{O} 2$ tensions and the prevention of differentiation of hES cells. Proc Natl Acad Sci U S A 102, 4783, 2005.

182. Zhao, F., Pathi, P., Grayson, W., Xing, Q., Locke, B.R., and Ma, T. Effects of oxygen transport on 3-d human mesenchymal stem cell metabolic activity in perfusion and static cultures: experiments and mathematical model. Biotechnol Prog 21, 1269, 2005.

183. Chow, D.C., Wenning, L.A., Miller, W.M., and Papoutsakis, E.T. Modeling $\mathrm{pO}(2)$ distributions in the bone marrow hematopoietic compartment. II. Modified Kroghian models. Biophys J 81, 685, 2001. 
184. Zahm, A.M., Bucaro, M.A., Ayyaswamy, P.S., Srinivas, V., Shapiro, I.M., Adams, C.S., and Mukundakrishnan, K. Numerical modeling of oxygen distributions in cortical and cancellous bone: oxygen availability governs osteonal and trabecular dimensions. Am J Physiol Cell Physiol 299, C922.

185. Deorosan, B., and Nauman, E.A. The role of glucose, serum, and three-dimensional cell culture on the metabolism of bone marrow-derived mesenchymal stem cells. Stem Cells Int 2011, 429187.

186. Deschepper, M., Manassero, M., Oudina, K., Paquet, J., Monfoulet, L.E., Bensidhoum, M., Logeart-Avramoglou, D., and Petite, H. Proangiogenic and prosurvival functions of glucose in human mesenchymal stem cells upon transplantation. Stem Cells 31, 526, 2013.

187. Sikavitsas, V.I., Bancroft, G.N., and Mikos, A.G. Formation of three-dimensional cell/polymer constructs for bone tissue engineering in a spinner flask and a rotating wall vessel bioreactor. J Biomed Mater Res 62, 136, 2002.

188. Martin, I., Wendt, D., and Heberer, M. The role of bioreactors in tissue engineering. Trends Biotechnol 22, 80, 2004.

189. Holtorf, H.L., Jansen, J.A., and Mikos, A.G. Modulation of cell differentiation in bone tissue engineering constructs cultured in a bioreactor. Advances in experimental medicine and biology 585, 225, 2006.

190. Grayson, W.L., Martens, T.P., Eng, G.M., Radisic, M., and Vunjak-Novakovic, G. Biomimetic approach to tissue engineering. Semin Cell Dev Biol 20, 665, 2009.

191. Rolfe, P. Sensing in tissue bioreactors. Measurement Science and Technology 17, 578, 2006.

192. Akyuz, E., Braun, J.T., Brown, N.A., and Bachus, K.N. Static versus dynamic loading in the mechanical modulation of vertebral growth. Spine (Phila Pa 1976) 31, E952, 2006.

193. Lanyon, L.E., and Rubin, C.T. Static vs dynamic loads as an influence on bone remodelling. J Biomech 17, 897, 1984.

194. Lanyon, L.E. Control of bone architecture by functional load bearing. J Bone Miner Res 7 Suppl 2, S369, 1992.

195. Verheyen, K., Price, J., Lanyon, L., and Wood, J. Exercise distance and speed affect the risk of fracture in racehorses. Bone 39, 1322, 2006.

196. Frost, H.M. Bone "mass" and the "mechanostat": a proposal. Anat Rec 219, 1, 1987.

197. Brown, T.D., Pedersen, D.R., Gray, M.L., Brand, R.A., and Rubin, C.T. Toward an identification of mechanical parameters initiating periosteal remodeling: a combined experimental and analytic approach. J Biomech 23, 893, 1990.

198. Sikavitsas, V.I., Temenoff, J.S., and Mikos, A.G. Biomaterials and bone mechanotransduction. Biomaterials 22, 2581, 2001.

199. Dillaman, R.M., Roer, R.D., and Gay, D.M. Fluid movement in bone: theoretical and empirical. J Biomech 24 Suppl 1, 163, 1991.

200. Keanini, R.G., Roer, R.D., and Dillaman, R.M. A theoretical model of circulatory interstitial fluid flow and species transport within porous cortical bone. J Biomech 28, 901, 1995.

201. Piekarski, K., and Munro, M. Transport mechanism operating between blood supply and osteocytes in long bones. Nature 269, 80, 1977.

202. Parton, R.G., and Simons, K. The multiple faces of caveolae. Nat Rev Mol Cell Biol 8, 185, 2007.

203. Katsumi, A., Orr, A.W., Tzima, E., and Schwartz, M.A. Integrins in mechanotransduction. J Biol Chem 279, 12001, 2004.

204. Davidson, R.M., Tatakis, D.W., and Auerbach, A.L. Multiple forms of mechanosensitive ion channels in osteoblast-like cells. Pflugers Archiv : European journal of physiology 416, 646, 1990.

205. Donahue, H.J., Li, Z., Zhou, Z., and Yellowley, C.E. Differentiation of human fetal osteoblastic cells and gap junctional intercellular communication. Am J Physiol Cell Physiol 278, C315, 2000.

206. Malone, A.M., Anderson, C.T., Stearns, T., and Jacobs, C.R. Primary cilia in bone. Journal of musculoskeletal \& neuronal interactions 7, 301, 2007.

207. Jackson, W.M., Jaasma, M.J., Tang, R.Y., and Keaveny, T.M. Mechanical loading by fluid shear is sufficient to alter the cytoskeletal composition of osteoblastic cells. Am J Physiol Cell Physiol 295, C1007, 2008. 
208. Ingber, D.E. Cellular mechanotransduction: putting all the pieces together again. Faseb $J$ 20, 811, 2006.

209. Botchwey, E.A., Dupree, M.A., Pollack, S.R., Levine, E.M., and Laurencin, C.T. Tissue engineered bone: measurement of nutrient transport in three-dimensional matrices. J Biomed Mater Res A 67, 357, 2003.

210. Hillsley, M.V., and Frangos, J.A. Bone tissue engineering: the role of interstitial fluid flow. Biotechnol Bioeng 43, 573, 1994.

211. Kreke, M.R., Sharp, L.A., Lee, Y.W., and Goldstein, A.S. Effect of intermittent shear stress on mechanotransductive signaling and osteoblastic differentiation of bone marrow stromal cells. Tissue Eng Part A 14, 529, 2008.

212. Grellier, M., Bareille, R., Bourget, C., and Amedee, J. Responsiveness of human bone marrow stromal cells to shear stress. J Tissue Eng Regen Med 3, 302, 2009.

213. Santos, A., Bakker, A.D., Zandieh-Doulabi, B., Semeins, C.M., and Klein-Nulend, J. Pulsating fluid flow modulates gene expression of proteins involved in Wnt signaling pathways in osteocytes. J Orthop Res 27, 1280, 2009.

214. Bancroft, G.N., Sikavitsas, V.I., van den Dolder, J., Sheffield, T.L., Ambrose, C.G., Jansen, J.A., and Mikos, A.G. Fluid flow increases mineralized matrix deposition in 3D perfusion culture of marrow stromal osteoblasts in a dose-dependent manner. Proc Natl Acad Sci U S A 99, 12600, 2002.

215. Sikavitsas, V.I., Bancroft, G.N., Lemoine, J.J., Liebschner, M.A., Dauner, M., and Mikos, A.G. Flow perfusion enhances the calcified matrix deposition of marrow stromal cells in biodegradable nonwoven fiber mesh scaffolds. Ann Biomed Eng 33, 63, 2005.

216. Porter, B.D., Lin, A.S., Peister, A., Hutmacher, D., and Guldberg, R.E. Noninvasive image analysis of 3D construct mineralization in a perfusion bioreactor. Biomaterials 28, 2525, 2007.

217. Owan, I., Burr, D.B., Turner, C.H., Qiu, J., Tu, Y., Onyia, J.E., and Duncan, R.L. Mechanotransduction in bone: osteoblasts are more responsive to fluid forces than mechanical strain. Am J Physiol 273, C810, 1997.

218. Gomes, M.E., Bossano, C.M., Johnston, C.M., Reis, R.L., and Mikos, A.G. In vitro localization of bone growth factors in constructs of biodegradable scaffolds seeded with marrow stromal cells and cultured in a flow perfusion bioreactor. Tissue Eng 12, 177, 2006.

219. Holtorf, H.L., Sheffield, T.L., Ambrose, C.G., Jansen, J.A., and Mikos, A.G. Flow perfusion culture of marrow stromal cells seeded on porous biphasic calcium phosphate ceramics. Ann Biomed Eng 33, 1238, 2005.

220. Sikavitsas, V.I., Bancroft, G.N., Holtorf, H.L., Jansen, J.A., and Mikos, A.G. Mineralized matrix deposition by marrow stromal osteoblasts in $3 \mathrm{D}$ perfusion culture increases with increasing fluid shear forces. Proc Natl Acad Sci U S A 100, 14683, 2003.

221. Jacobs, C.R., Yellowley, C.E., Davis, B.R., Zhou, Z., Cimbala, J.M., and Donahue, H.J. Differential effect of steady versus oscillating flow on bone cells. J Biomech 31, 969, 1998.

222. Turner, C.H. Three rules for bone adaptation to mechanical stimuli. Bone 23, 399, 1998.

223. Dumas, V., Ducharne, B., Perrier, A., Fournier, C., Guignandon, A., Thomas, M., Peyroche, S., Guyomar, D., Vico, L., and Rattner, A. Extracellular matrix produced by osteoblasts cultured under low-magnitude, high-frequency stimulation is favourable to osteogenic differentiation of mesenchymal stem cells. Calcif Tissue Int 87, 351.

224. Jaasma, M.J., Plunkett, N.A., and O'Brien, F.J. Design and validation of a dynamic flow perfusion bioreactor for use with compliant tissue engineering scaffolds. J Biotechnol 133, 490, 2008.

225. Vance, J., Galley, S., Liu, D.F., and Donahue, S.W. Mechanical stimulation of MC3T3 osteoblastic cells in a bone tissue-engineering bioreactor enhances prostaglandin E2 release. Tissue Eng 11, 1832, 2005.

226. Correia, C., Bhumiratana, S., Sousa, R.A., Reis, R.L., and Vunjak-Novakovic, G. Sequential application of steady and pulsatile medium perfusion enhanced the formation of engineered bone. Tissue Eng Part A 19, 1244, 2013.

227. Alvarez-Barreto, J.F., and Sikavitsas, V.I. Improved mesenchymal stem cell seeding on RGDmodified poly(L-lactic acid) scaffolds using flow perfusion. Macromol Biosci 7, 579, 2007. 
228. Hutmacher, D.W., and Singh, H. Computational fluid dynamics for improved bioreactor design and 3D culture. Trends Biotechnol 26, 166, 2008.

229. Yan X., C.X.B., Bergstrom D.J. Modeling of the Flow within Scaffolds in Perfusion Bioreactors. American Journal of Biomedical Engineering 1, 72, 2011.

230. Cartmell, S.H., Porter, B.D., Garcia, A.J., and Guldberg, R.E. Effects of medium perfusion rate on cell-seeded three-dimensional bone constructs in vitro. Tissue Eng 9, 1197, 2003.

231. Weinbaum, S., Cowin, S.C., and Zeng, Y. A model for the excitation of osteocytes by mechanical loading-induced bone fluid shear stresses. J Biomech 27, 339, 1994.

232. Bakker, A.D., Soejima, K., Klein-Nulend, J., and Burger, E.H. The production of nitric oxide and prostaglandin $E(2)$ by primary bone cells is shear stress dependent. J Biomech 34, 671, 2001.

233. Alford, A.I., Jacobs, C.R., and Donahue, H.J. Oscillating fluid flow regulates gap junction communication in osteocytic MLO-Y4 cells by an ERK1/2 MAP kinase-dependent mechanism. Bone 33, 64, 2003.

234. Kapur, S., Baylink, D.J., and Lau, K.H. Fluid flow shear stress stimulates human osteoblast proliferation and differentiation through multiple interacting and competing signal transduction pathways. Bone 32, 241, 2003.

235. Bacabac, R.G., Smit, T.H., Mullender, M.G., Dijcks, S.J., Van Loon, J.J., and Klein-Nulend, J. Nitric oxide production by bone cells is fluid shear stress rate dependent. Biochem Biophys Res Commun 315, 823, 2004.

236. Knippenberg, M., Helder, M.N., Doulabi, B.Z., Semeins, C.M., Wuisman, P.I., and Klein-Nulend, J. Adipose tissue-derived mesenchymal stem cells acquire bone cell-like responsiveness to fluid shear stress on osteogenic stimulation. Tissue Eng 11, 1780, 2005.

237. Kreke, M.R., Huckle, W.R., and Goldstein, A.S. Fluid flow stimulates expression of osteopontin and bone sialoprotein by bone marrow stromal cells in a temporally dependent manner. Bone $\mathbf{3 6}$, 1047, 2005.

238. Mullender, M.G., Dijcks, S.J., Bacabac, R.G., Semeins, C.M., Van Loon, J.J., and Klein-Nulend, J. Release of nitric oxide, but not prostaglandin E2, by bone cells depends on fluid flow frequency. J Orthop Res 24, 1170, 2006.

239. Vetsch, J.R., Muller, R., and Hofmann, S. The evolution of simulation techniques for dynamic bone tissue engineering in bioreactors. J Tissue Eng Regen Med 2013.

240. Porter, B., Zauel, R., Stockman, H., Guldberg, R., and Fyhrie, D. 3-D computational modeling of media flow through scaffolds in a perfusion bioreactor. J Biomech 38, 543, 2005.

241. Cioffi, M., Boschetti, F., Raimondi, M.T., and Dubini, G. Modeling evaluation of the fluiddynamic microenvironment in tissue-engineered constructs: a micro-CT based model. Biotechnol Bioeng 93, 500, 2006.

242. Song, K., Wang, H., Zhang, B., Lim, M., Liu, Y., and Liu, T. Numerical simulation of fluid field and in vitro three-dimensional fabrication of tissue-engineered bones in a rotating bioreactor and in vivo implantation for repairing segmental bone defects. Cell stress \& chaperones 18, 193, 2013.

243. VanGordon S.B., V.R.S., Blue T.B., Shambaugh R.L., Papavassiliou D.V., Sikavitsas V.I. Effects of scaffold architecture on preosteoblastic cultures under continuous fluid shear. Industrial \& Engineering Chemistry Research 50, 620, 2011.

244. Maes, F., Claessens, T., Moesen, M., Van Oosterwyck, H., Van Ransbeeck, P., and Verdonck, P. Computational models for wall shear stress estimation in scaffolds: a comparative study of two complete geometries. J Biomech 45, 1586, 2012.

245. Boschetti, F., Raimondi, M.T., Migliavacca, F., and Dubini, G. Prediction of the micro-fluid dynamic environment imposed to three-dimensional engineered cell systems in bioreactors. J Biomech 39, 418, 2006.

246. Sandino, C., Planell, J.A., and Lacroix, D. A finite element study of mechanical stimuli in scaffolds for bone tissue engineering. J Biomech 41, 1005, 2008.

247. Jungreuthmayer, C., Jaasma, M.J., Al-Munajjed, A.A., Zanghellini, J., Kelly, D.J., and O'Brien, F.J. Deformation simulation of cells seeded on a collagen-GAG scaffold in a flow perfusion bioreactor using a sequential 3D CFD-elastostatics model. Med Eng Phys 31, 420, 2009. 
248. McCoy, R.J., Jungreuthmayer, C., and O'Brien, F.J. Influence of flow rate and scaffold pore size on cell behavior during mechanical stimulation in a flow perfusion bioreactor. Biotechnol Bioeng 109, 1583, 2012.

249. Demarteau, O., Jakob, M., Schafer, D., Heberer, M., and Martin, I. Development and validation of a bioreactor for physical stimulation of engineered cartilage. Biorheology 40, 331, 2003.

250. Wartella, K.A., and Wayne, J.S. Bioreactor for biaxial mechanical stimulation to tissue engineered constructs. J Biomech Eng 131, 044501, 2009.

251. Tschumperlin, D.J., Dai, G., Maly, I.V., Kikuchi, T., Laiho, L.H., McVittie, A.K., Haley, K.J., Lilly, C.M., So, P.T., Lauffenburger, D.A., Kamm, R.D., and Drazen, J.M. Mechanotransduction through growth-factor shedding into the extracellular space. Nature 429, 83, 2004.

252. Bolgen, N., Yang, Y., Korkusuz, P., Guzel, E., El Haj, A.J., and Piskin, E. Three-dimensional ingrowth of bone cells within biodegradable cryogel scaffolds in bioreactors at different regimes. Tissue Eng Part A 14, 1743, 2008.

253. Jagodzinski, M., Breitbart, A., Wehmeier, M., Hesse, E., Haasper, C., Krettek, C., Zeichen, J., and Hankemeier, S. Influence of perfusion and cyclic compression on proliferation and differentiation of bone marrow stromal cells in 3-dimensional culture. J Biomech 41, 1885, 2008.

254. Baas, E., Kuiper, J.H., Yang, Y., Wood, M.A., and El Haj, A.J. In vitro bone growth responds to local mechanical strain in three-dimensional polymer scaffolds. J Biomech 43, 733, 2010.

255. Hagenmuller, H., Hitz, M., Merkle, H.P., Meinel, L., and Muller, R. Design and validation of a novel bioreactor principle to combine online micro-computed tomography monitoring and mechanical loading in bone tissue engineering. The Review of scientific instruments 81, 014303, 2010.

256. Van Dyke, W.S., Sun, X., Richard, A.B., Nauman, E.A., and Akkus, O. Novel mechanical bioreactor for concomitant fluid shear stress and substrate strain. J Biomech 45, 1323, 2012.

257. Kasseck, C., Kratz, M., Torcasio, A., Gerhardt, N.C., van Lenthe, G.H., Gambichler, T., Hoffmann, K., Jones, D.B., and Hofmann, M.R. Comparison of optical coherence tomography, microcomputed tomography, and histology at a three-dimensionally imaged trabecular bone sample. J Biomed Opt 15, 046019, 2010.

258. Yang, Y., Dubois, A., Qin, X.P., Li, J., El Haj, A., and Wang, R.K. Investigation of optical coherence tomography as an imaging modality in tissue engineering. Phys Med Biol 51, 1649, 2006.

259. Liang, X., Graf, B.W., and Boppart, S.A. Imaging engineered tissues using structural and functional optical coherence tomography. J Biophotonics 2, 643, 2009.

260. Jaedicke, V., Agcaer, S., Robles, F.E., Steinert, M., Jones, D., Goebel, S., Gerhardt, N.C., Welp, H., and Hofmann, M.R. Comparison of different metrics for analysis and visualization in spectroscopic optical coherence tomography. Biomedical optics express 4, 2945, 2013.

261. Cartmell, S., Huynh, K., Lin, A., Nagaraja, S., and Guldberg, R. Quantitative microcomputed tomography analysis of mineralization within three-dimensional scaffolds in vitro. J Biomed Mater Res A 69, 97, 2004.

262. Cancedda, R., Cedola, A., Giuliani, A., Komlev, V., Lagomarsino, S., Mastrogiacomo, M., Peyrin, F., and Rustichelli, F. Bulk and interface investigations of scaffolds and tissue-engineered bones by $X-$ ray microtomography and X-ray microdiffraction. Biomaterials 28, 2505, 2007.

263. Bernhardt, R., Scharnweber, D., Muller, B., Thurner, P., Schliephake, H., Wyss, P., Beckmann, F., Goebbels, J., and Worch, H. Comparison of microfocus- and synchrotron X-ray tomography for the analysis of osteointegration around Ti6AI4V implants. Eur Cell Mater 7, 42, 2004.

264. Nuzzo, S., Peyrin, F., Cloetens, P., Baruchel, J., and Boivin, G. Quantification of the degree of mineralization of bone in three dimensions using synchrotron radiation microtomography. Med Phys 29, 2672, 2002.

265. Komlev, V.S., Mastrogiacomo, M., Peyrin, F., Cancedda, R., and Rustichelli, F. X-ray synchrotron radiation pseudo-holotomography as a new imaging technique to investigate angio- and microvasculogenesis with no usage of contrast agents. Tissue Eng Part C Methods 15, 425, 2009. 


\section{Tables}

Table 1: Effects of shear stresses on bone cells seeded on glass in parallel plate flow chambers

\begin{tabular}{|c|c|c|c|c|}
\hline References & Cell types & $\begin{array}{c}\text { Shear } \\
\text { stress level }\end{array}$ & Shear stress regimen & Observations \\
\hline $\begin{array}{l}\text { Bakker, } 2001 \\
\text { (232) }\end{array}$ & $\begin{array}{l}\text { Mouse primary cells from } \\
\text { adult long bone }\end{array}$ & $\begin{array}{l}0.4 \mathrm{~Pa}, 0.6 \\
\mathrm{~Pa} \text { and } 1.2 \\
\mathrm{~Pa}\end{array}$ & $\begin{array}{l}\text { Pulsating fluid flow, } \\
3 \mathrm{~Hz}, 5 \mathrm{~Hz} \text { or } 9 \mathrm{~Hz}, \\
15 \mathrm{~min}\end{array}$ & $\mathrm{NO}$ and $\mathrm{PGE}_{2}$ production \\
\hline $\begin{array}{l}\text { Alford, } 2003 \\
\text { (233) }\end{array}$ & $\begin{array}{l}\text { Mouse osteocyte-like cell } \\
\text { line, MLOY-4 }\end{array}$ & $1 \mathrm{~Pa}$ & $\begin{array}{l}\text { Oscillating fluid flow, } \\
1 \mathrm{~Hz}, 1 \mathrm{~h}\end{array}$ & $\begin{array}{l}\text { Phosphorylation of } \mathrm{Cx} 43 \\
\text { Up-regulation of GJIC }\end{array}$ \\
\hline $\begin{array}{l}\text { Kapur, } 2003 \\
(234)\end{array}$ & $\begin{array}{l}\text { Human primary } \\
\text { osteoblasts from mandible } \\
\text { bone chips }\end{array}$ & $2 \mathrm{~Pa}$ & $\begin{array}{l}\text { Steady fluid flow, } \\
\text { 30min }\end{array}$ & $\begin{array}{l}\text { Increase of }\left[{ }^{3} \mathrm{H}\right] \text { thymidine incorporation, ALP } \\
\text { activity, phosphorylation of ERK and expression } \\
\text { of integrin } \beta 1\end{array}$ \\
\hline $\begin{array}{l}\text { Bacabac, } 2004 \\
(235)\end{array}$ & $\begin{array}{l}\text { Mouse pre-osteoblast cell } \\
\text { line, MC3T3-E1 }\end{array}$ & $0.7 \mathrm{~Pa}$ & $\begin{array}{l}\text { Steady and pulsating } \\
\text { fluid flow, } 5 \text { or } 9 \mathrm{~Hz} \\
15 \mathrm{~min}\end{array}$ & $\begin{array}{l}\text { NO production }\left(\mathrm{NO}_{2}^{-} \text {accumulated in the }\right. \\
\text { conditionel medium) }\end{array}$ \\
\hline $\begin{array}{l}\text { Knippenberg, } \\
2005 \\
(236)\end{array}$ & $\begin{array}{l}\text { Goat primary } \\
\text { mesenchymal stem cells } \\
\text { from adipose tissue }\end{array}$ & $0.6 \mathrm{~Pa}$ & $\begin{array}{l}\text { Pulsating fluid flow, } \\
5 \mathrm{~Hz}, 1 \mathrm{~h}\end{array}$ & $\begin{array}{l}\text { Increase of NO production and upregulation of } \\
\text { Cox } 2 \text { gene expression }\end{array}$ \\
\hline $\begin{array}{l}\text { Kreke, } 2005 \\
(237)\end{array}$ & $\begin{array}{l}\text { Rat primary bone marrow } \\
\text { stromal cell culture }\end{array}$ & $0.16 \mathrm{~Pa}$ & $\begin{array}{l}\text { Steady fluid flow, } \\
5 \mathrm{~min}, 30 \mathrm{~min} \text { or } \\
120 \mathrm{~min}\end{array}$ & $\begin{array}{l}\text { Increase of ALP activity, increase of the } \\
\text { expression of osteopontin and bone sialoprotein } \\
\text { mRNA, increase of } \mathrm{PGE}_{2}\end{array}$ \\
\hline $\begin{array}{l}\text { Mullender, } \\
2006 \\
(238)\end{array}$ & $\begin{array}{l}\text { Mouse pre-osteoblast cell } \\
\text { line, MC3T3-E1 }\end{array}$ & $\begin{array}{l}0.18 \text { and } \\
0.64 \mathrm{~Pa}\end{array}$ & $\begin{array}{l}\text { Steady and pulsating } \\
\text { fluid flow, } 1 \mathrm{~Hz}, 5 \mathrm{~Hz} \text { or } \\
9 \mathrm{~Hz}, 15 \mathrm{~min}\end{array}$ & NO and PGE2 production increased \\
\hline $\begin{array}{l}\text { Kreke, } 2008 \\
(211)\end{array}$ & $\begin{array}{l}\text { Rat primary bone marrow } \\
\text { stromal cell culture }\end{array}$ & $0.23 \mathrm{~Pa}$ & $\begin{array}{l}\text { Continuous and } \\
\text { intermittent ( } 5 \mathrm{~min} \\
\text { on } / 5 \mathrm{~min} \text { off) fluid } \\
\text { flow, } 24 \mathrm{~h}\end{array}$ & $\begin{array}{l}\text { Increase of the phosphorylation of ERK and p38 } \\
\text { Increase of } \mathrm{PGE}_{2}\end{array}$ \\
\hline $\begin{array}{l}\text { Grellier, } 2009 \\
(212)\end{array}$ & $\begin{array}{l}\text { Human primary bone } \\
\text { marrow stromal cell } \\
\text { culture }\end{array}$ & $1.2 \mathrm{~Pa}$ & $\begin{array}{l}\text { Steady fluid flow, } \\
30 \mathrm{~min} \text { and } 90 \mathrm{~min}\end{array}$ & $\begin{array}{l}\text { Gene expression : ALP increased, Cx43 increased, } \\
\text { Col I decreased } \\
\text { Phosphorylation of ERK } 1 / 2 \text { and p38 }\end{array}$ \\
\hline
\end{tabular}


Table 2: Numerical models prediction of shear stress values induced by flow within scaffolds

\begin{tabular}{|c|c|c|c|}
\hline References & Scaffold & Numerical method & $\begin{array}{c}\text { Calculated mean wall } \\
\text { shear stress }\end{array}$ \\
\hline $\begin{array}{l}\text { Porter, } 2005 \\
(240)\end{array}$ & Human trabecular bone & Lattice-Boltzmann & $0.05 \mathrm{mPa}$ \\
\hline $\begin{array}{l}\text { Boschetti, } 2006 \\
(245)\end{array}$ & Polylactic acid (PLLA) porous scaffold & Finite element method & $\begin{array}{l}3.7 \mathrm{mPa} \text { (« Reference } \\
\text { model ») }\end{array}$ \\
\hline Cioffi, 2006 (241) & $\begin{array}{l}\text { Biodegradable polyestherurethane foam } \\
\text { scaffold }\end{array}$ & Finite volume method & $\begin{array}{l}3.94,3.73 \text {, and } 3.28 \mathrm{mPa} \text { vs } \\
\text { model }\end{array}$ \\
\hline Cioffi, 2008 (70) & $\begin{array}{l}\text { Polyethylene glycol } \\
\text { terephthalate/polybutylene } \\
\text { terephthalate (PEGT/PBT) foam scaffold }\end{array}$ & Finite volume method & $\begin{array}{l}2.56 \text { and } 0.256 \mathrm{mPa} \text { vs inlet } \\
\text { flow }\end{array}$ \\
\hline $\begin{array}{l}\text { Sandino, } 2008 \\
(308)\end{array}$ & $\begin{array}{l}\text { Porous and biodegradable scaffolds: } \\
\text { caclium phosphate and glass }\end{array}$ & Finite element method & $0.05 \mathrm{mPa}$ (Modal values) \\
\hline Milan, 2009 (71) & PLLA-glass scaffold & Finite element method & $\begin{array}{l}\text { Between } 0.04 \mathrm{mPa} \text { and } \\
40 \mathrm{mPa} \text { vs inlet flow }\end{array}$ \\
\hline $\begin{array}{l}\text { Melchels, } 2011 \\
\text { (50) }\end{array}$ & $\begin{array}{l}2 \text { PLLA scaffolds with gyroid pore } \\
\text { architectures }\end{array}$ & Finite volume method & 31 and $27 \mathrm{mPa}$ \\
\hline Yan 2011, (229) & $\begin{array}{l}\text { Chitosan-hydroxyapatite scaffolds with } \\
\text { regular structure }\end{array}$ & Finite element method & Between 1 and $7 \mathrm{mPa}$ \\
\hline $\begin{array}{l}\text { VanGordon, } 2011 \\
(243)\end{array}$ & $\begin{array}{l}\text { PLLA porous foam scaffold and } \\
\text { nonwoven fiber mesh scaffold }\end{array}$ & Lattice-Boltzmann & $\begin{array}{l}\text { Between } 12 \mathrm{mPa} \text { and } 25 \\
\mathrm{mPa} \text { vs inlet flow and } \\
\text { geometry }\end{array}$ \\
\hline Maes, 2012 (244) & Titanium and hydroxyapatite scaffolds & Finite volume method & 1.41 and $1.09 \mathrm{mPa}$ \\
\hline
\end{tabular}


Table 3: Direct mechanical loading of cells seeded scaffolds - Modalities and effects

\section{Bouet.Table3}

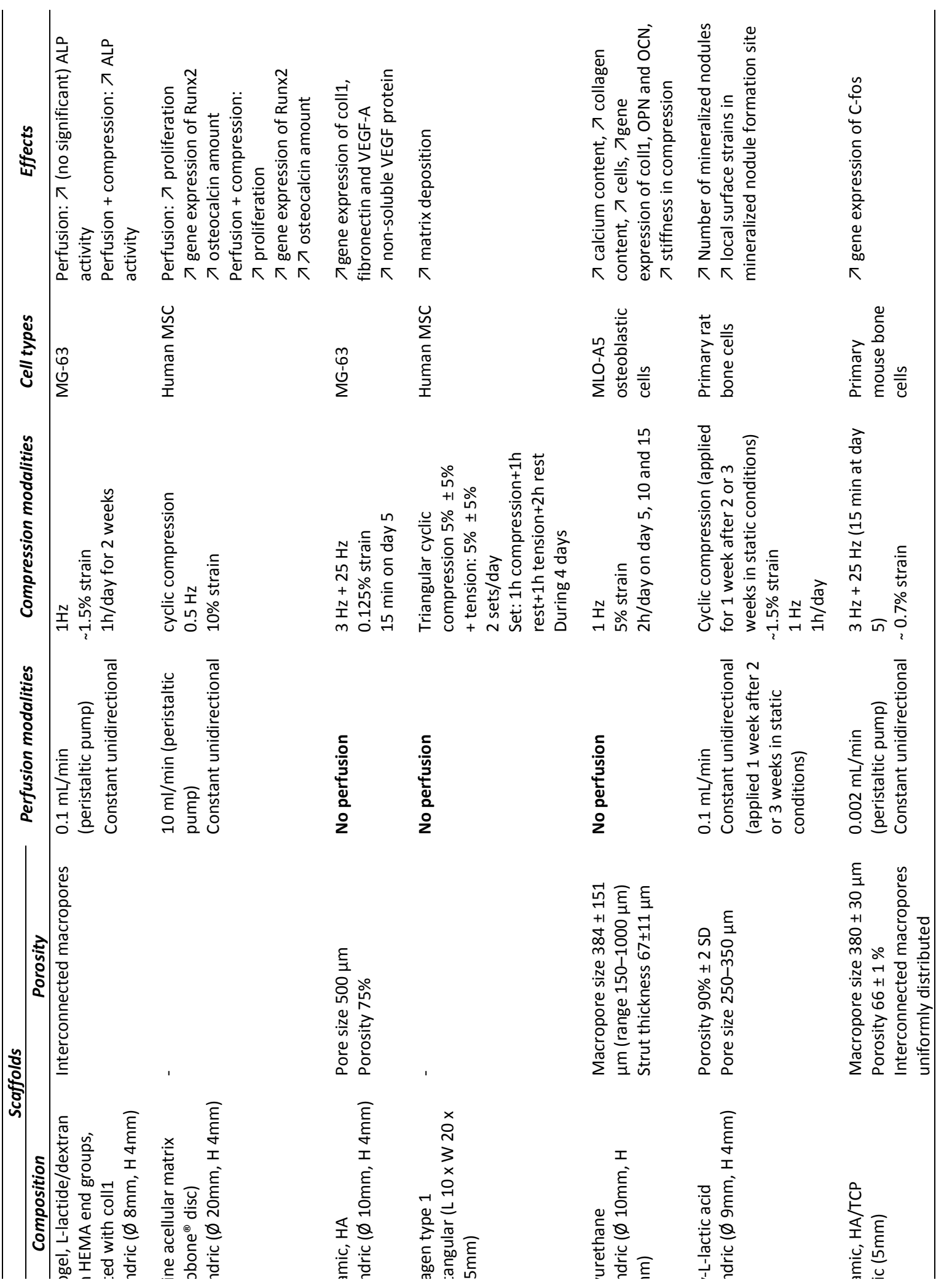




\section{Figures}
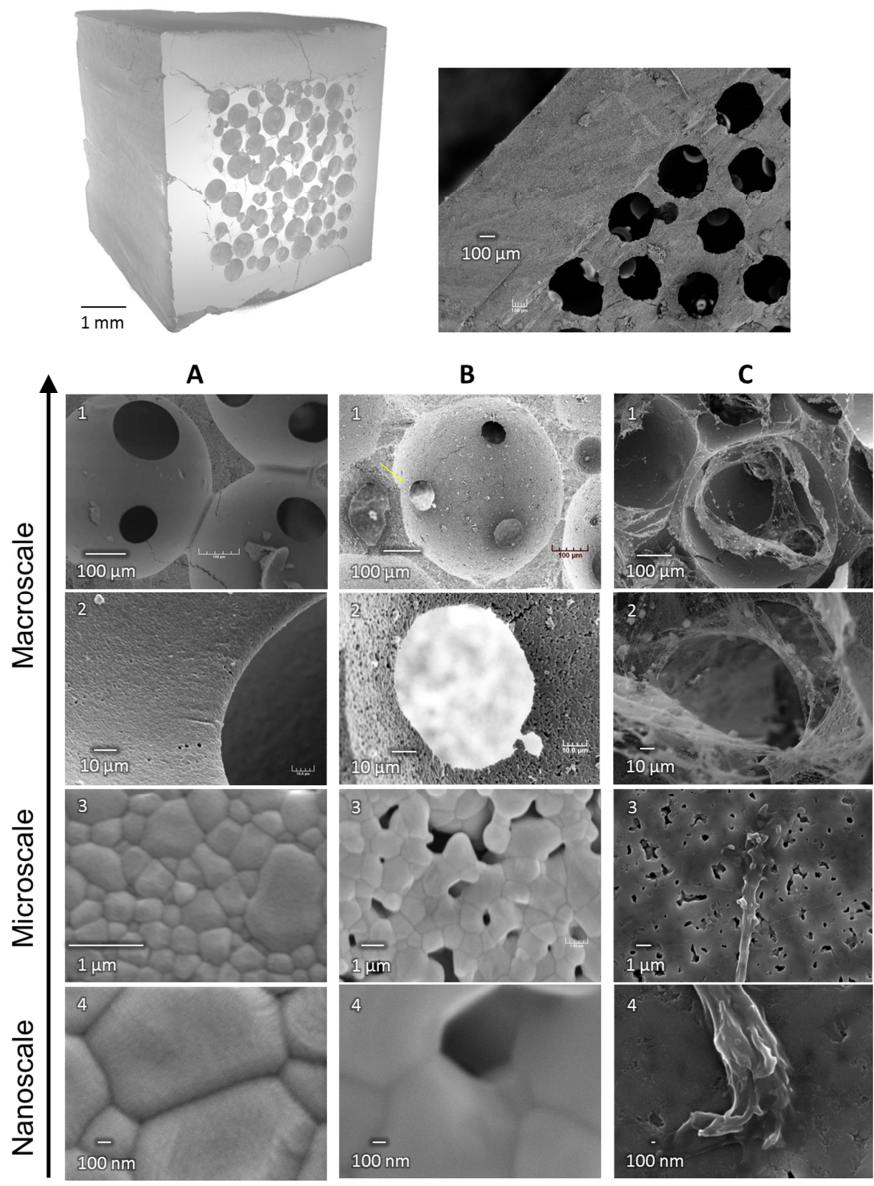

Figure 1. Images from micro-computed tomography (m-CT) and scanning electron microscopy (SEM) of CaP scaffolds manufactured through standard replication of PMMA (Polymethyl Methacrylate) template, $(\mathrm{A})$ without micropore, with micropores (B) before and (C) after 7 days of culture in perfusion bioreactor with mouse calvarial cells (steady flow of 2 $\mu \mathrm{L} / \mathrm{min})$; the yellow arrow on image B1 displays the interconnection pore magnified in image B2. 
A Perfusion bioreactor

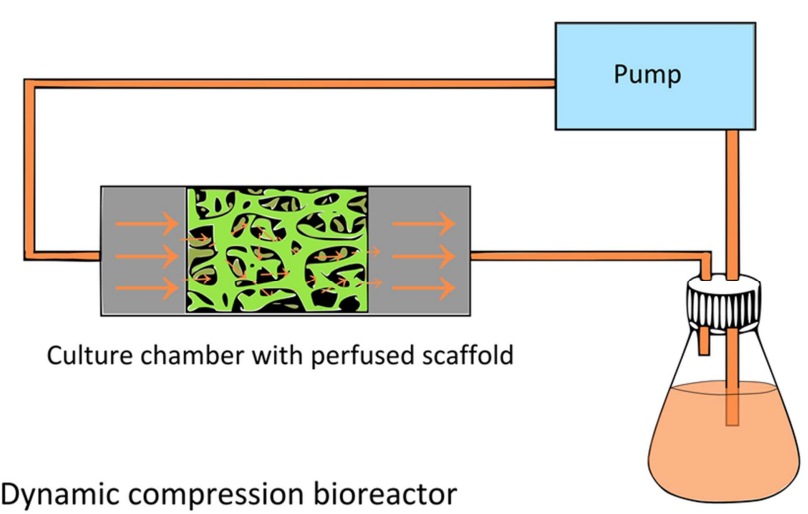

B Dynamic compression bioreactor

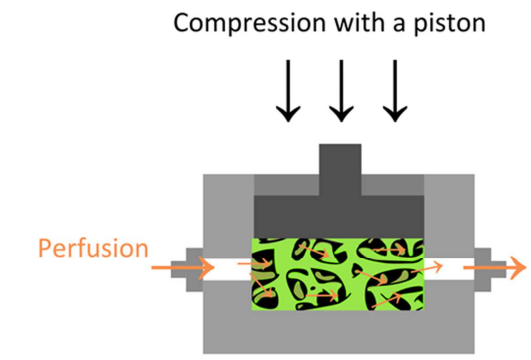

Culture chamber with perfused and compressed scaffold

Figure 2. Models of bioreactors. (A) Example of perfusion bioreactor in which the culture medium is forced through the internal interconnected porous network of the seeded scaffold. This can override diffusion limitations and enhance nutrient delivery and waste removal from the cultured cells. The setup includes a medium reservoir, a pump and a tubing system which feeds the culture chamber; (B) Example of perfusion bioreactor allowing the application of controlled dynamic compression to the scaffolds perpendicularly to fluid flow in a dissociated or combined manner. 


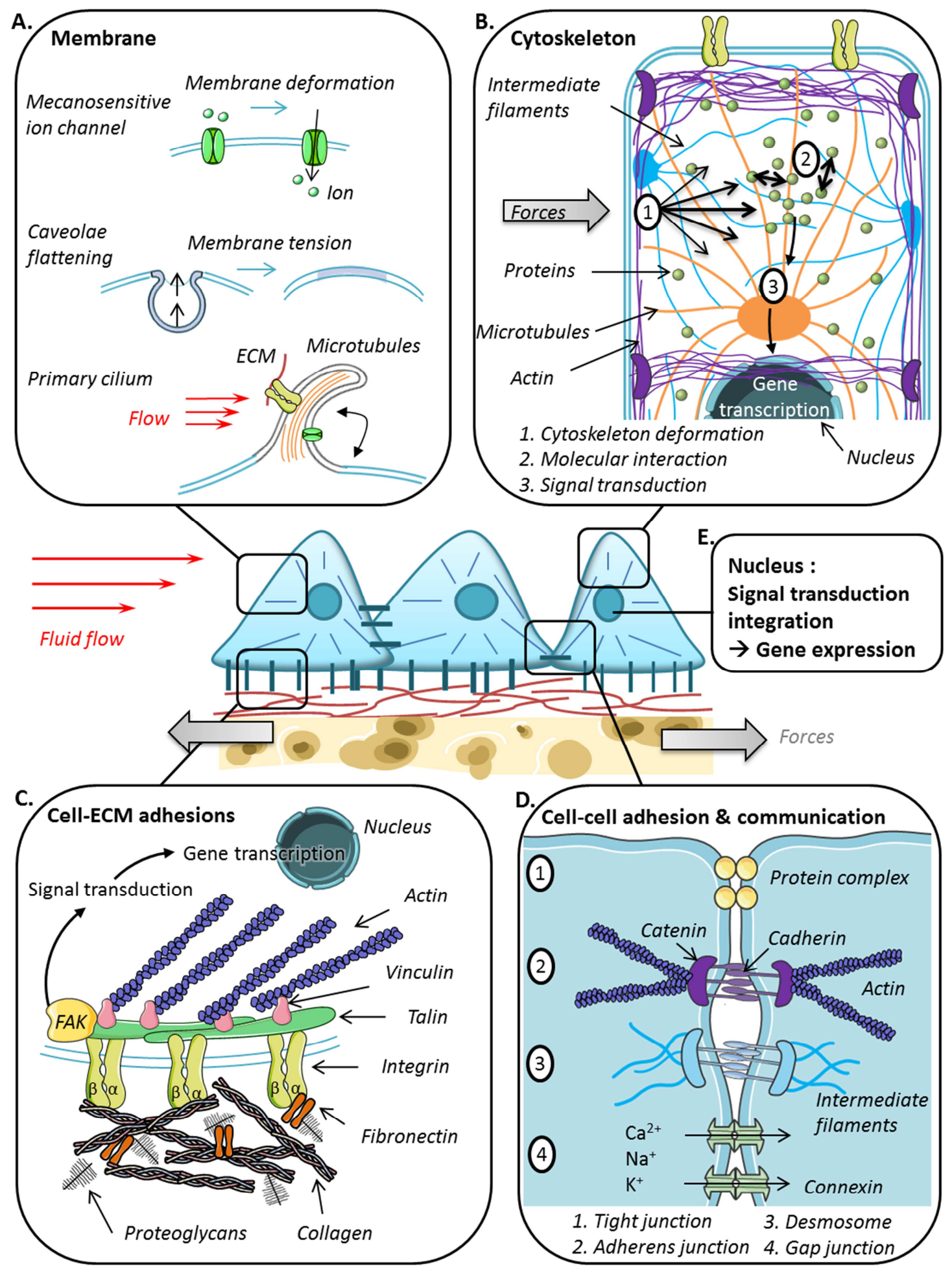

Figure 3. Actors and mechanisms of cellular mechanosensing. Mechanical forces can be sensed and transduced by different means through membrane and/or organelle deformation or cell/ECM interactions. 
(A) At the cell membrane level, mechanosensitive ions channels and caveolae (not yet demonstrated in bone cell but in endothelial cells (202)) detect fluid flow or membrane stretching. Ion channels respond by gating, leading to the entry of ions inside cell (203) and caveolae by flattening and activation of specific signaling pathways. Moreover, bone cells possess a single microtubule-based primary cilium which projects from the cell surface and is deflected by fluid flow (206). Its membrane contains receptors and channels which participate in numerous signaling events and play an important role in the mediation of flow-induced calcium deposition by osteoblasts (206).

(B) Mechanical stimulation leads to cell cytoskeletal deformation including actin (stress fiber) reorientation, microtubule polymerization/depolymerisation and intracellular protein displacement (concentration) permitting their interaction and effecting the signal transduction of the original force (207).

(C) As the main cellular mechanical detection mechanism, the transmembrane receptors integrins bind to ECM proteins (e.g. collagen, fibronectin) and activate a mechanosensory protein complex (involving talin, vinculin and focal adhesion kinase (FAK) linked to a kinase cascade system (203).

(D) Cell-cell adhesion, via tight (1) and adherens junctions (2) as well as desmosomes (3), precedes and controls intercellular communication via gap junctions (4), transcellular channels formed by the matching of connexin protein complexes between two neighboring cells. Gap junctions are involved in the propagation of intercellular calcium waves which activate mechanosensitive signal transduction pathways (205).

(E) The multiple transduction signal pathways are integrated by the nucleus and induce changes in gene expression and protein production leading to cell behavior adaptation. 


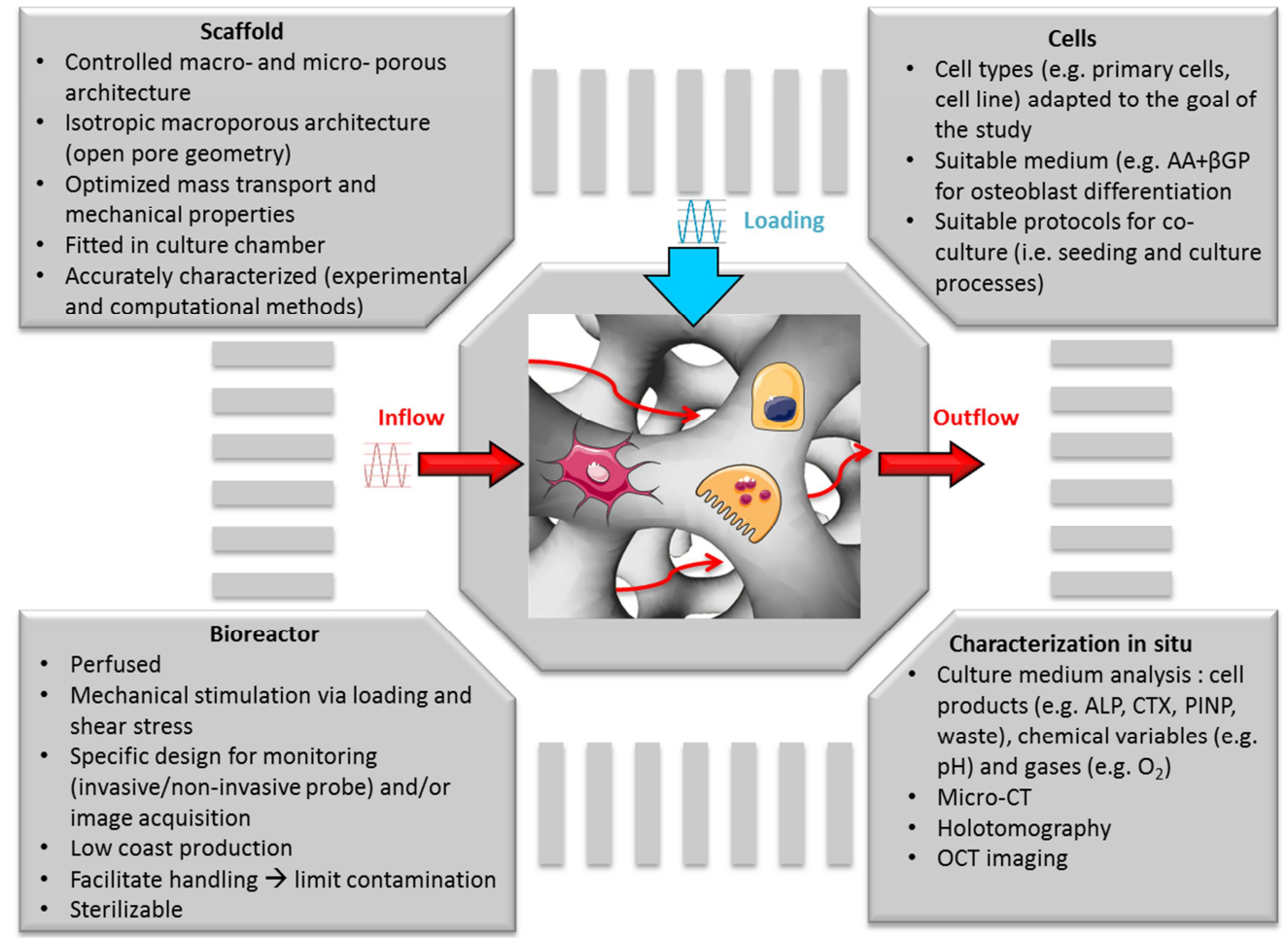

Figure 4. Schematic representation of the key elements of in vitro 3D culture model including: cell type choice depending on the goal of the study, main scaffold and bioreactor features needed, as well as characterization tools.

Abbreviations: $A A=$ ascorbic acid,$\beta G P=\beta$-glycerophosphate,$A L P=$ alkaline phosphatase, CTX $=$ carboxy-terminal collagen crosslinks, PINP = amino-terminal propeptide of type I collagen, $\mathrm{OCT}=$ optical coherence tomography, micro-CT = micro-computed tomography . 